Marquette University

e-Publications@Marquette

\title{
Aluminum-containing Layered Double Hydroxides: the Thermal, Mechanical, and Fire Properties of (Nano)composites of Poly(methyl Methacrylate)
}

\author{
Charles Manzi-Nshuti \\ Marquette University \\ Dongyan Wang \\ Cornell University \\ Jeanne Hossenlopp \\ Marquette University, jeanne.hossenlopp@marquette.edu \\ Charles A. Wilkie \\ Marquette University, charles.wilkie@marquette.edu
}

Follow this and additional works at: https://epublications.marquette.edu/chem_fac

Part of the Chemistry Commons

\section{Recommended Citation}

Manzi-Nshuti, Charles; Wang, Dongyan; Hossenlopp, Jeanne; and Wilkie, Charles A., "Aluminum-containing Layered Double Hydroxides: the Thermal, Mechanical, and Fire Properties of (Nano)composites of Poly(methyl Methacrylate)" (2008). Chemistry Faculty Research and Publications. 10.

https://epublications.marquette.edu/chem_fac/10 


\title{
Aluminum-Containing Layered Double Hydroxides: the Thermal, Mechanical, and Fire Properties of (Nano)Composites of Poly(Methyl Methacrylate)*
}

\author{
Charles Manzi-Nshuti \\ Department of Chemistry, Marquette University \\ Milwaukee, WI \\ Dongyan Wang \\ Department of Materials Science \& Engineering \\ Cornell University \\ Ithaca, NY \\ Jeanne M. Hossenlopp \\ Department of Chemistry, Marquette University \\ Milwaukee, WI \\ Charles A. Wilkie \\ Department of Chemistry, Marquette University \\ Milwaukee, WI
}


Hydrotalcite-like anionic clays or layered double hydroxides (LDHs) of the general formula, $\left[\mathrm{M}^{I-x} \mathrm{M}^{I I I} \times(\mathrm{OH})_{2}\right]_{\text {intra }}\left[\left(\mathrm{CH}_{2}=\mathrm{CH}\left(\mathrm{CH}_{2}\right)_{8} \mathrm{COO}^{-}\right.\right.$ )$\left._{x} \cdot \mathrm{nH}_{2} \mathrm{O}\right]_{\text {inter, }}$ with $\mathrm{M}^{I I I}=\mathrm{Al}$ and $\mathrm{M}^{I I}=\mathrm{Co}, \mathrm{Ni}, \mathrm{Cu}$, and $\mathrm{Zn}$, have been prepared by the co-precipitation method and used to prepare nanocomposites with poly(methyl methacrylate) (PMMA). One goal of this work was to compare the morphology, thermal, fire and mechanical properties with those of the well-known PMMAmontmorillonite system. The thermal properties of these systems are greatly improved relative to the virgin PMMA, with ZnAl2 and CoAl2 being the best systems when $50 \%$ mass loss is the point of comparison. NiAl2, on the other hand, is more thermally stable when $10 \%$ mass loss was the point of comparison. The mechanical properties, such as Young's Modulus and elongation, were not significantly impacted by nanocomposite formation. The cone calorimetric results showed that the PMMA-CoAl2 system gives the best reduction ( $41 \%$ ) in peak heat release rate (PHRR); this value is significantly larger than that seen for the PMMA-montmorillonite system. Small improvements were observed for the nickel-containing LDH with the same polymer. XRD of the char produced in the cone calorimeter, and after heating to $1000^{\circ} \mathrm{C}$, suggest the formation of a mixture of the spinel and the $M^{I I}$ oxide for $\mathrm{Zn}, \mathrm{Cu}$ and Ni systems while only the spinel was identified in the case of PMMA-CoAl2 systems.

\section{Introduction}

In recent years, polymer-inorganic nanocomposites have been the subject of extensive research. Previous studies on the layered materials have mainly focused on the layered silicates and polymerlayered silicate nanocomposites, ${ }^{1}$ because of the relatively low layer charge density and the easy exfoliation of montmorillonite (MMT)-type layered silicate compounds. Anionic clays are also of interest as they may have properties that are parallel to or divergent from those of the cationic clays. The most well-known anionic clays are the hydrotalcitelike layered double hydroxides or LDHs. ${ }^{2}$

LDHs have a much higher charge density than MMT in the interlayer and a stronger interaction among the hydroxide sheets than layered silicates, which makes the exfoliation of LDHs much more difficult. ${ }^{3}$ Recently, a number of reports on the exfoliation of $\mathrm{LDHs}^{4}$ and 
polymer-LDH exfoliated nanocomposites ${ }^{5}$ have been published. These synthetic anionic clays are emerging as potential fire retardants. ${ }^{6}$

Layered double hydroxides consist of positively charged metal hydroxides sheets with anions (along with water) located between the layers to compensate the charge on the layers. ${ }^{7}$ The $\mathrm{LDH}$ structure is described with the ideal formula $\left[\mathrm{M}^{\mathrm{II}}{ }_{1-x} \mathrm{M}^{\mathrm{III}}{ }_{x}(\mathrm{OH})_{2}\right]_{\text {intra }}\left[\mathrm{A}^{m-}{ }_{x / m} \cdot n \mathrm{H}_{2} \mathrm{O}\right]_{\text {inter, }}$, where $\mathrm{M}^{\mathrm{II}}$ is a divalent cation such as $\mathrm{Mg}, \mathrm{Co}, \mathrm{Ni}, \mathrm{Cu}$, or $\mathrm{Zn}$ and $\mathrm{M}^{\mathrm{III}}$ is a trivalent cation such as $\mathrm{Al}, \mathrm{Cr}, \mathrm{Fe}, \mathrm{V}$, or $\mathrm{Ga}$ with $\mathrm{A}^{m-} x / m$ an anion of charge $m$ such as $\mathrm{NO}_{3}{ }^{-}, \mathrm{CO}_{3}{ }^{2-}, \mathrm{Cl}^{-}, \mathrm{SO}_{4}{ }^{2-}, \mathrm{C}_{12} \mathrm{H}_{25} \mathrm{SO}_{4}{ }^{-}$, and various carboxylates, etc.; intra and inter denote the intralayer domain and the interlayer space, respectively. The LDH structure consists of brucite-like layers constituted of edge-sharing $\mathrm{M}(\mathrm{OH})_{6}$ octahedra. ${ }^{8}$ Partial $\mathrm{M}^{\mathrm{III}}$ for $\mathrm{M}^{\mathrm{II}}$ substitution induces a positive charge on the layers, balanced by the presence of the interlayer anions. LDHs then consist of a stacking of positively charged layers with anions intercalated in the interlayer region, usually referred to as the gallery space, together with water molecules. LDHs exhibit anion-exchange properties ${ }^{9}$ and their interlayer spacing can change depending on the size of the intercalated anions. ${ }^{10}$ When heated above about $600{ }^{\circ} \mathrm{C}$, these materials lead to mixed oxides. ${ }^{11}$

The presence of an organic moiety in the LDH gallery space plays an important role in the preparation of the $\mathrm{LDH}$-polymer nanocomposites. Pinnavaia et al. ${ }^{12}$ reported a $\mathrm{Mg}^{2+} / \mathrm{Al}^{3+} / \mathrm{Cl}^{-} \mathrm{LDH}$ with a gallery height of approximately $2.97 \AA$. The size of the interlayer space was calculated from a basal spacing of $7.74 \AA$ (indicated by $X$-ray powder diffraction) and the thickness of the brucite layer (4.77 $\AA$ ). The gallery distance between each pair of pristine LDH layers, such as the hydrotalcite mentioned above, is too small to allow monomer or polymer molecules to intercalate. The gallery anion then plays a role as a spacer. But also, as is the case for their cationic counterparts (for example, sodium montmorillonite), the hydrophilic surface of the LDH layers is incompatible with hydrophobic polymer molecules (except for some water soluble polymers, not used in this work). For these two reasons, LDHs cannot be easily dispersed in the hydrophobic polymer matrix as the monomers or polymer molecules are not able to easily penetrate into the LDH layers. Chen and Qu reported the exfoliation of dodecyl sulfate modified MgAl LDH with polyethylene-graft-maleic 
anhydride (PE-g-MA) in xylene solution to form PE-g-MA-MgAl LDH nanocomposites. ${ }^{6 a}$ Many other examples are in the literature where some organic or polymeric anions, such as alkyl carboxylates, ${ }^{5}$ alkyl sulfates, ${ }^{6,13}$ acrylate-based monomers, ${ }^{14}$ and poly(styrene sulfonates) ${ }^{15}$ were intercalated into the interlayer of the LDHs by an ion-exchange reaction or in situ polymerization. The incorporation of these anions into the gallery space of the LDHs was accompanied by an expansion of the basal spacing. ${ }^{16}$

LDHs present the advantage of a large variety of compositions and a tunable charge density, ${ }^{17}$ based on changes in stoichiometry. This is of importance because the presence of interlayer species is directly related to the net layer charge values. For comparison, sodium montmorillonite $\left(\mathrm{Na}_{0 .} 35 \mathrm{~K}_{0.01} \mathrm{Ca}_{0.02}\right)\left(\mathrm{Si}_{3.89} \mathrm{Al}_{0.11}\right)$ $\left(\mathrm{Al}_{1.6} \mathrm{Fe}_{0.08} \mathrm{Mg}_{0.32}\right) \mathrm{O}_{10}(\mathrm{OH})_{2}$ presents an exchange capacity of 108 milliequivalents $/ 100 \mathrm{~g},{ }^{18}$ giving an area per charge of $70 \AA$ charge $^{-1}$, whereas it ranges between 25 and $40 \AA$ charge $^{-1}$ for LDH materials. The effect of stoichiometry (and hence charge density) of MgAl and $\mathrm{NiAl}$ LDHs on the anion-exchange of carbonate by the decavanadate anion has been reported. ${ }^{19} \mathrm{~A}$ variation in the $\mathrm{M}^{\mathrm{II}} / \mathrm{M}^{\mathrm{III}}$ ratio between 2 and 6 was attempted with the influence of the $\mathrm{M}^{\mathrm{II}} / \mathrm{M}^{\mathrm{III}}$ ratio upon exchange examined. For $\mathrm{M}^{\mathrm{II}} / \mathrm{M}^{\mathrm{III}}$ ratios $>4$, the product crystallinity is poor. Compared with the MgAl LDH, transition metal bearing LDHs (such as FeAl, CoAl, NiAl, etc.) are known to have broader technological applications due to their special catalytic, electronic, optical, and magnetic properties. ${ }^{4,20}$

In this work, the synthesis of LDHs containing zinc-aluminum, cobalt-aluminum, nickel-aluminum and copper-aluminum undecenoate under similar conditions and the thermal, mechanical and fire properties of their PMMA nanocomposites are evaluated. These metals were chosen as representative of the range of divalent metals that can be used in the formation of an LDH. Aluminum was chosen as the trivalent metal cation for all the LDHs as the goal was to compare the role of the divalent metals on the properties of the polymer composites. The undecenoate anion was chosen as the spacer in the $\mathrm{LDH}$ since the volume of this anion is large and this anion contains a polymerizable end group ${ }^{21}$ which, based on previous work with montmorillonite, ${ }^{22}$ should help in future work to obtain exfoliated nanocomposites. The results discussed in this paper, however, focus permission has been granted for this version to appear in e-Publications@Marquette. Royal Society of Chmistry does not grant permission for this article to be further copied/distributed or hosted elsewhere without the express permission from Royal Society of Chmistry. 
on the samples prepared by a melt blending process which does not take advantage of this double bond. Further work is underway, using bulk polymerization, which will make use of the terminal double bond and will enable a comparison with this work.

The overall goal of the ongoing work is to identify the role of the different components, such as the metals and anions, of these synthetic layered materials in the dispersability and properties of new polymeric (nano)composites. While polymer-MMT nanocomposites have been widely investigated and trends identified in the relationship between nanocomposite formation and polymer physical properties, ${ }^{1}$ the effects of LDH additives on polymers are less well understood. The results presented here provide a detailed examination of structureproperty relationships in polymer-LDH (nano)composites in order to obtain new insight into the role that nanocomposite formation plays on influencing polymer physical (thermal, mechanical, and fire) properties.

\section{Experimental}

\section{Materials}

Poly(methyl methacrylate), typical MW 120 000, was obtained from Aldrich Chemical Co. Zinc nitrate hexahydrate, (98\%), cobalt (II) nitrate hexahydrate, (98\%), copper (II) nitrate hydrate, (98\%), and aluminum nitrate nonahydrate, (98\%), were also obtained from Aldrich Chemical Co. Nickel (II) nitrate hexahydrate, (99\%), 10undecenoic acid, (99\%), sodium hydroxide, extra pure pellets, were purchased from Acros Organics. All chemicals were used without further purification.

\section{Preparation of the undecenoate LDHs}

The 10-undecenoate-containing LDHs were synthesized by adopting the co-precipitation method ${ }^{5}$ as reported by Wang et al., with some modifications. The preparation was performed in a N2 atmosphere to exclude carbon dioxide from the LDHs. The pHs adopted were the ones reported by Kuma et al. ${ }^{23}$ The basic strategy involved addition of an $\mathrm{M}^{\mathrm{II}} / \mathrm{M}^{\mathrm{III}}$ metal salt solution to a basic solution of 
the desired anions. ${ }^{24}$ In a typical experiment, in a $3000 \mathrm{ml}$ three neck flask under a flow of nitrogen to exclude $\mathrm{CO}_{2}, 1000 \mathrm{ml}$ of distilled water were boiled for 30 min while purging with nitrogen, then cooled to room temperature. To this water and $0.2 \mathrm{~mol}$ of $\mathrm{NaOH}$ were added, and the mixture stirred until the $\mathrm{NaOH}$ completely dissolved. Then, 0.2 mol of undecenoic acid was added to the above solution and the solution stirred until it was homogenous. In a separate flask, a solution of nickel nitrate $(0.2 \mathrm{~mol})$ and aluminum nitrate $(0.1 \mathrm{~mol})$ in $500 \mathrm{ml}$ of degassed water was prepared. The nitrate solution was slowly added dropwise to the stirred undecenoate- $\mathrm{NaOH}$ solution at room temperature, maintaining the $\mathrm{pH}$ at the desired value, using a $1 \mathrm{M}$ $\mathrm{NaOH}$ solution. For example, in the case of nickel aluminum undecenoate $\mathrm{LDH}$, or $\mathrm{NiAl} 2$, the $\mathrm{pH}$ was maintained at $8.8 \pm 0.1$. After all the nitrate solution was added, the resulting slurry mixture was aged for $24 \mathrm{~h}$ at $50^{\circ} \mathrm{C}$, filtered, washed (degassed water) and dried in a vacuum oven at $65^{\circ} \mathrm{C}$ for $12 \mathrm{~h}$. The syntheses of cobalt aluminum undecenoate LDH, or CoAl2, and copper aluminum undecenoate LDH or CuAl2, were performed as described above except that nickel nitrate was replaced by $0.2 \mathrm{~mol}$ of cobalt nitrate or copper nitrate $(0.2 \mathrm{~mol})$ and that the pHs were adjusted to $11.1 \pm 0.1$ and $8.9 \pm 0.1$, respectively.

To study the role of the metal ratio of an LDH and the properties of its corresponding polymer composite, two different zinc aluminum LDHs were synthesized: in the synthesis of the first one, the molar ratio of zinc to aluminum was set at 2 to 1 and this LDH was identified as $\mathrm{ZnAl2}$, while the other LDH identified as $\mathrm{ZnAl3}$, the ratio of zinc to aluminum was set at 3 to 1 . The synthesis of these zinc containing LDHs followed the above described method, but after adding the nitrates, the slurry was aged at $80{ }^{\circ} \mathrm{C}$ and the $\mathrm{pH}$ in this synthesis was set to 10 . All LDHs were characterized by X-ray diffraction, FT-IR, elemental analysis and thermogravimetric analysis.

The results obtained from elemental analysis are as follows: found for $\mathrm{ZnAl} 2,31.6 \% \mathrm{Zn}, 6.04 \% \mathrm{Al}, 27.8 \% \mathrm{C}, 5.53 \% \mathrm{H},<0.05 \% \mathrm{~N}$ with atomic ratio $\mathrm{Zn} / \mathrm{Al}=2.16$; calculated for $\mathrm{ZnAl} 2,31.2 \% \mathrm{Zn}$, $5.96 \% \mathrm{Al}, 27.6 \% \mathrm{C}, 5.41 \% \mathrm{H}$ with the formula $\mathrm{Zn}_{2.16} \mathrm{Al}(\mathrm{OH})_{6.32}\left(\mathrm{C}_{11} \mathrm{H}_{19} \mathrm{O}_{2}\right)_{0.943}\left(\mathrm{CO}_{3}\right)_{0.029} \cdot 0.133 \mathrm{H}_{2} \mathrm{O}$. Found for $\mathrm{ZnAl3}$, $27.2 \% \mathrm{Zn}, 3.56 \% \mathrm{Al}, 35.1 \% \mathrm{C}, 6.42 \% \mathrm{H}, 0.18 \% \mathrm{~N}$ with atomic ratio permission has been granted for this version to appear in e-Publications@Marquette. Royal Society of Chmistry does not grant permission for this article to be further copied/distributed or hosted elsewhere without the express permission from Royal Society of Chmistry. 
NOT THE PUBLISHED VERSION; this is the author's final, peer-reviewed manuscript. The published version may be accessed by following the link in the citation at the bottom of the page.

$\mathrm{Zn} / \mathrm{Al} 1 \frac{1}{4} 3.15$; calculated for ZnAl3, 27.6\% Zn, 3.61\% Al, 35.6\% C, $6.53 \% \mathrm{H}$ corresponding to the formula $\mathrm{Zn}_{3.15} \mathrm{Al}(\mathrm{OH})_{8.30}\left(\mathrm{C}_{11} \mathrm{H}_{19} \mathrm{O}_{2}\right)\left(\mathrm{HC}_{11} \mathrm{H}_{19} \mathrm{O}_{2}\right)_{1.02} \cdot 0.344 \mathrm{H}_{2} \mathrm{O}$. Found for $\mathrm{NiAl}$, $20.9 \% \mathrm{Ni}, 5.29 \% \mathrm{Al}, 35.3 \% \mathrm{C}, 6.86 \% \mathrm{H}, 0.03 \% \mathrm{~N}$ with atomic ratio $\mathrm{Ni} / \mathrm{Al}=1.81$; calculated for $\mathrm{NiAl} 2,20.5 \% \mathrm{Ni}, 5.21 \% \mathrm{Al}, 34.8 \% \mathrm{C}$, $6.76 \% \mathrm{H}$ suggesting the formula $\mathrm{Ni}_{1.81} \mathrm{Al}(\mathrm{OH})_{5.62}\left(\mathrm{C}_{11} \mathrm{H}_{19} \mathrm{O}_{2}\right)\left(\mathrm{HC}_{11} \mathrm{H}_{19} \mathrm{O}_{2}\right)_{0.365} \cdot 1.73 \mathrm{H}_{2} \mathrm{O}$. Found for CuAl2, $22.4 \% \mathrm{Cu}, 4.78 \% \mathrm{Al}, 36.6 \% \mathrm{C}, 6.87 \% \mathrm{H}, 0.10 \% \mathrm{~N}$ with the atomic ratio $\mathrm{Cu} / \mathrm{Al}=1.99$; calculated for $\mathrm{CuAl} 2,22.3 \% \mathrm{Cu}, 4.76 \% \mathrm{Al}, 36.5 \%$ $\mathrm{C}, 6.89 \% \mathrm{H}$ corresponding to the formula $\mathrm{Cu}_{1.99} \mathrm{Al}(\mathrm{OH})_{5.98}\left(\mathrm{C}_{11} \mathrm{H}_{19} \mathrm{O}_{2}\right)\left(\mathrm{HC}_{11} \mathrm{H}_{19} \mathrm{O}_{2}\right)_{0.566} \cdot 1.37 \mathrm{H}_{2} \mathrm{O}$. Found for CoAl2, $24.4 \% \mathrm{Co}, 5.59 \% \mathrm{Al}, 27.8 \% \mathrm{C}, 6.22 \% \mathrm{H}, 0.01 \% \mathrm{~N}$ with the atomic ratio $\mathrm{Co} / \mathrm{Al}=2.00$; calculated for $\mathrm{CoAl} 2,24.8 \% \mathrm{Co}, 5.68 \% \mathrm{Al}, 28.3 \%$ $\mathrm{C}, 6.38 \% \mathrm{H}$ with the formula $\mathrm{CO}_{2.00 \mathrm{Al}}$ $(\mathrm{OH})_{6.00}\left(\mathrm{C}_{11} \mathrm{H}_{19} \mathrm{O}_{2}\right)\left(\mathrm{HC}_{11} \mathrm{H}_{19} \mathrm{O}_{2}\right)_{0.02} \cdot 2.31 \mathrm{H}_{2} \mathrm{O}$

\section{Preparation of nanocomposites}

The nanocomposites were prepared by melt blending. The PMMA nanocomposites were prepared in a Brabender Plasticorder at high speed $(60 \mathrm{rpm})$ at $185^{\circ} \mathrm{C}$ for $7 \mathrm{~min}$. The composition of each nanocomposite is calculated from the amount of layered double hydroxide and the polymer charged to the Brabender.

\section{Instrumentation}

X-Ray diffraction (XRD) measurements of the LDHs were performed on a Bruker-Nonius APEX2 with CCD detector with $0.5 \mathrm{~mm}$ Monocap collimator and graphite monochromator with $\mathrm{Cu} \mathrm{K} \alpha$ generator $(\lambda=1.54078 \AA)$ from a sealed $X$-ray tube. The powder sample was prepared as a $0.3 \mathrm{~mm}$ ball using a small amount of mineral oil and was put on the top of a $0.1 \mathrm{~mm}$ nylon pin. The data were collected at various $2 \theta$ values in $9^{\circ}$ increments using $180^{\circ} \Phi$ rotations. The polymeric samples were compression molded into $20 \mathrm{~mm} \times 15 \mathrm{~mm} \times$ $1 \mathrm{~mm}$ plaques for XRD measurements on a Scintag equipped with a $\mathrm{Cu}$ K $\alpha$ generator $(\lambda=1.54056 \AA)$ scanning from $1^{\circ}$ to $10^{\circ}$ at $0.02^{\circ}$ step size. Fourier transform infrared (FT-IR) spectra of the solid materials were obtained using the $\mathrm{KBr}$ method on a Nicolet Magna-IR 560 spectrometer operated at $1 \mathrm{~cm}^{-1}$ resolution in the $400-4000 \mathrm{~cm}^{-1}$

Journal of Materials Chemistry, Vol. 18, No. 26 (2008): pg. 3091-3102. DOI. This article is (C) Royal Society of Chmistry and permission has been granted for this version to appear in e-Publications@Marquette. Royal Society of Chmistry does not grant permission for this article to be further copied/distributed or hosted elsewhere without the express permission from Royal Society of Chmistry. 
region. Elemental analysis was carried out by Huffman Labs, Colorado, using atomic emission spectroscopy interfaced with inductively coupled plasma (AES-ICP) for metal determination. Thermogravimetric analysis (TGA) was performed on a SDT 2960 machine (TA Instruments) at the $15 \mathrm{mg}$ scale under air or a flowing nitrogen atmosphere at a scan rate of $20{ }^{\circ} \mathrm{C} \mathrm{min}-1$. Temperatures are reproducible to $\pm 3{ }^{\circ} \mathrm{C}$, while the error on the fraction of non-volatile materials is $\pm 2 \%$. Bright field transmission electron microscopy (TEM) images of the composites were obtained at $80 \mathrm{kV}$ with a Zeiss $10 \mathrm{c}$ electron microscope. The samples were ultramicrotomed with a diamond knife on a RiechertJung Ultra-Cut E microtome at room temperature to give $\sim 70 \mathrm{~nm}$ thick sections. These sections were transferred from a knife-edge to 600 hexagonal mesh $\mathrm{Cu}$ grids. The contrast between the layered silicates and the polymer phase was sufficient for imaging, so no heavy metal staining of sections prior to imaging is required. Tensile properties were measured on an Instron 5500 series testing instrument. The reported values are the average of ten determinations. Cone calorimeter measurements were performed on an Atlas CONE-2 according to ASTM E 1352 at $50 \mathrm{~kW} \mathrm{~m}^{-2}$ incident flux using a cone shaped heater; the exhaust flow was set at $24 \mathrm{I} \mathrm{sec}^{-1}$. The specimens for cone calorimetry were prepared by the compression molding of the sample (about $30 \mathrm{~g}$ ) into $3 \times 100 \times 100 \mathrm{~mm}^{3}$ square plaques. Typical results from cone calorimetry are reproducible to within about $\pm 10 \%$; these uncertainties are based on many runs in which thousands of samples have been combusted. ${ }^{25}$

\section{Results and Discussion}

\section{Characterization of undecenoate LDHs}

The presence and type of organic moiety in the gallery space of layered materials play an important role in the preparation of inorganic-polymer nanocomposites. ${ }^{5}$ Thus, the first step in this work was to synthesize LDHs with an organophilic anion which is long enough to cause expansion of the gallery space to permit the incorporation of the polymer matrix. XRD data indicated that layered materials were formed with basal spacings of $2.76 \mathrm{~nm}$ for CuAl2, 2.73 $\mathrm{nm}$ for CoAl2, $2.70 \mathrm{~nm}$ for NiAl2 and $2.74 \mathrm{~nm}$ for ZnAl2, and $3.10 \mathrm{~nm}$ for $\mathrm{ZnAl3}$, consistent with interdigitated or tilted bilayer orientation of permission has been granted for this version to appear in e-Publications@Marquette. Royal Society of Chmistry does not grant permission for this article to be further copied/distributed or hosted elsewhere without the express permission from Royal Society of Chmistry. 
the undecanoate anion. Detailed discussion of the XRD and FTIR analysis can be found in the ESI*.

The ratios of the metals in both the starting material and the LDH that was obtained correlate very well. This was also observed by Wang et al., who reported that the ratios of the divalent to the trivalent metal cations was maintained at $2: 1$ in both the reactants and the MgAl-undecenoate LDH they produced. ${ }^{5}$ This observation was attributed to the fact that the solubility of the metal (II) hydroxide greatly exceeds that of aluminum hydroxide. ${ }^{26}$ It must be noted that chemical analysis does not rule out the possibility of erroneous values as a result of precipitation of $\mathrm{M}(\mathrm{OH})_{2}$ and/or $\mathrm{Al}(\mathrm{OH})_{3}$ phases upon the LDH surfaces, which are possibly amorphous and therefore not detected by XRD. ${ }^{7}$ A small amount of nitrogen was found in these materials, with the smallest amount of $0.01 \%$ in CoAl2 and the highest amount of $0.10 \%$ found in $\mathrm{ZnAl3}$. As these materials were prepared from nitrate precursors, nitrogen content is thought to originate from either an incomplete exchange of the materials or nitrate may be incorporated in such a way that it is not removable. For the purpose of this work, it is assumed that such a low percentage of nitrates in the LDHs will not affect the properties of the corresponding polymer composites.

Since the carbon content of $\mathrm{ZnAl} 3, \mathrm{NiAl} 2$ and $\mathrm{CuAl} 2$ was relatively high, it is assumed that the excess organic moiety was perhaps due to some protonated anions also present in the material produced. Usually, the presence of a peak around $1596 \mathrm{~cm}^{-1}$ is attributed to the asymmetric $v_{\mathrm{c}=\mathrm{o}}$ of a $\mathrm{H}$-bonded carboxylic acid in the interlayer of the LDH material. ${ }^{27}$ The intercalation of such free acid groups $^{28}$ is a general phenomenon, when excess carboxylate anions are used in the exchange or preparation, even at such a high $\mathrm{pH}^{29}$ Work is currently underway to investigate how the excess of organic moieties in the LDH layers may affect the thermal stability and the mechanical and fire properties of the polymers.

\section{Thermal properties}

The TGA and the corresponding derivatized mass, DTG, curves of the various $\mathrm{LDHs}$ heated in a nitrogen environment at $20^{\circ} \mathrm{C} \mathrm{min}-1$ permission has been granted for this version to appear in e-Publications@Marquette. Royal Society of Chmistry does not grant permission for this article to be further copied/distributed or hosted elsewhere without the express permission from Royal Society of Chmistry. 
from $80-780^{\circ} \mathrm{C}$ are shown in Fig. 1 . It is noted that overall the thermal decomposition of these LDHs is very complex with multiple events taking place. As can be seen in Fig. 1 however, there are some similarities when these materials are subjected to similar heating conditions. The mass loss before $350{ }^{\circ} \mathrm{C}$ can be attributed to the loss of external surface water, gallery water ${ }^{30}$ and to the partial dehydroxylation of the layers. Above $350{ }^{\circ} \mathrm{C}$, all LDHs show a main degradation step that can be associated with the decomposition of the intercalated undecenoate anion and further dehydroxylation of the layers leading to complete destruction of the LDH material. More work must be done in order to completely understand the thermal degradation of these materials. It should be pointed out that the amount of char at $800{ }^{\circ} \mathrm{C}$ varies from $37 \%, 38 \%, 44 \%, 48 \%$ to $53 \%$ for CuAl2, NiAl2, CoAl2, ZnAl3 and ZnAl2, respectively, and, except for $\mathrm{ZnAl} 3$, the mass remaining at $800{ }^{\circ} \mathrm{C}$ agrees well with the expected mass from the calculated formulae, assuming that mixed oxides were the product at $800{ }^{\circ} \mathrm{C}(37 \%, 36 \%, 42 \%, 41 \%$ and $50 \%$ respectively for CuAl2, NiAl2, CoAl2, ZnAl3 and ZnAl2). The decomposition of ZnAl3 leads to more than one product, notably $\mathrm{ZnO}$ and a mixed metal oxide as will be shown later in this paper.

\section{PMMA-LDH systems}

The XRD patterns of the PMMA-LDHs are shown along with those of the LDH precursors (Fig. 2). Except for the PMMA- CoAl2 system, where a shift towards a smaller $2 \theta$ value is observed indicating some intercalation of the polymer between the LDH layers, no significant change in the $d$-spacing is observed for the other PMMA$\mathrm{LDH}$ systems, which may be an indication of the formation of microcomposites. PMMA-ZnAl2 and PMMA-ZnAl3 systems show similar patterns (no change in the peak position after melt blending) and only the PMMA-ZnAl2 system is shown in Fig. 2. XRD alone is not sufficient to characterize the nature of the dispersion of additives in a polymer matrix and transmission electron microscopy (TEM) is also required. TEM provides direct imaging of the nanocomposite structure and filler dispersion, allowing a good assessment of the dispersion of the nanofiller.

Journal of Materials Chemistry, Vol. 18, No. 26 (2008): pg. 3091-3102. DOI. This article is @ Royal Society of Chmistry and permission has been granted for this version to appear in e-Publications@Marquette. Royal Society of Chmistry does not grant permission for this article to be further copied/distributed or hosted elsewhere without the express permission from Royal Society of Chmistry. 
NOT THE PUBLISHED VERSION; this is the author's final, peer-reviewed manuscript. The published version may be accessed by following the link in the citation at the bottom of the page.

The TEM image at low magnification is used to determine the dispersion of the layered material in the polymer while the higher magnification image enables the description of the material as intercalated or exfoliated. Fig. 3 provides the TEM images of PMMAZnAl2 (A), CoAl2 (B), NiAl2 (C) and ZnAl3 (D) both at low (left side) and high magnification (right side). In the case of the PMMA-CoAl2 system (B), the low magnification image shows good dispersion and the high magnification image suggests intercalation. The PMMA-ZnAl2 system shows relatively good dispersion with a few small tactoids. Poor dispersion is noted for PMMA-NiAI2 (C) and PMMA-ZnAI3 (D). Combining XRD and TEM results leaves the PMMA-CoAl2 system as the only nanocomposite while the other LDHs lead to immiscible systems.

\section{Mechanical properties of PMMA-LDH systems}

The mechanical properties of the PMMA-LDH systems were measured and the data are summarized in Table 1. The Instron gives tensile strength, elongation at break and Young's modulus can be also computed. It is well known that the mechanical properties of nanocomposites of layered silicates are enhanced relative to those of the virgin polymer. ${ }^{1}$ Little work on mechanical properties of LDH polymer systems has been reported. As noted in the summary table, replacing a small portion of polymer with these additives had essentially no effect on the mechanical properties of the polymeric system. Young's moduli of the virgin polymer and the different systems at both 5\% and $10 \%$ LDH loading were found to be around 1.1 GPa. The last four entries of Table 1 compare the two ZnAl LDHs. For the first two entries, the ratios of the divalent to trivalent metal cations were $2: 1$ while for the last two entries, the ratio of the metals was $3: 1$. This change did not affect the mechanical properties of the PMMA-LDH systems. These mechanical properties results must be compared to these of PMMA-MMT systems where nanocomposite formation leads to enhanced mechanical properties. In the LDH systems, one of these systems, PMMA-CoAI2, is dispersed at the nanometre level and can be described as a nanocomposite while the others are micro-composites. Surprisingly, the mechanical properties are not different. This observation indicates that LDH and MMT composites do not follow the same pattern and requires further investigation.

Journal of Materials Chemistry, Vol. 18, No. 26 (2008): pg. 3091-3102. DOI. This article is @ Royal Society of Chmistry and permission has been granted for this version to appear in e-Publications@Marquette. Royal Society of Chmistry does not grant permission for this article to be further copied/distributed or hosted elsewhere without the express permission from Royal Society of Chmistry. 
NOT THE PUBLISHED VERSION; this is the author's final, peer-reviewed manuscript. The published version may be accessed by following the link in the citation at the bottom of the page.

\section{Thermal analysis of PMMA-LDH systems}

There are many papers in literature concerning the thermal degradation of poly(methyl methacrylate) and its corresponding nanocomposites. ${ }^{31}$ The role, if any, of the different metals of an LDH on the thermal or fire properties of the corresponding polymer nanocomposites has never been addressed. It has been shown, however, that selected synthetic layered materials could efficiently improve the thermal stability of PMMA. For example, Chen and coworkers reported an improvement of about $45^{\circ} \mathrm{C}$ for PMMA-30\% MgAl (dodecyl sulfate) relative to virgin PMMA when $50 \%$ mass loss was used as the point of comparison. ${ }^{32}$

The thermal stability of commercial PMMA ( $\left.M_{\mathrm{w}} 120000\right)$, which was used in preparing samples described in Fig. 4 and 5 , has been compared relative to the same material melt blended at $185^{\circ} \mathrm{C}$ for 7 min, to determine if PMMA undergoes degradation during melt blending. There are no significant differences between the two samples which assures that significant polymer degradation does not occur (the reproducibility of the data from the TGA instrument is $\pm 3 \%$ ). The TGA curves are shown in the ESI*. This commercial PMMA shows two main steps in its degradation. The first step is attributed to scission at the unsaturated ends due to termination by disproportionation, a process involving a homolytic cleavage of the $\mathrm{C}-\mathrm{C}$ bond $\beta$ to the vinyl group, while the last step is due to the random chain scission of the PMMA backbone. ${ }^{33}$ The typical small mass loss of PMMA at lower temperatures attributed to weak linkages (such as head-to-head linkages ${ }^{33,34}$ ) was not observed in these samples.

From Fig. 4 and 5 and the summary of TGA results in Table 2, $\mathrm{NiAl} 2$ at both $5 \%$ and $10 \%$ additive loading seems to lead to a more thermally stable PMMA system when the temperature at $10 \%$ mass loss, $T_{0.1}$, is the comparison while PMMA-CoAI2 and PMMA-ZnAl2 systems are more stable at $50 \%$ mass loss relative to pure PMMA. The samples were run in a nitrogen atmosphere, at a heating ramp rate of

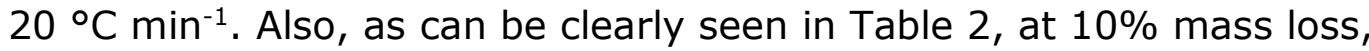
the PMMA-NiAl2 sample is more thermally stable than the other metalcontaining PMMA-LDHs at a loading of $5 \%$ or $10 \%$. The nickelcontaining samples degrade in one step, or the first step is much less

Journal of Materials Chemistry, Vol. 18, No. 26 (2008): pg. 3091-3102. DOI. This article is @ Royal Society of Chmistry and permission has been granted for this version to appear in e-Publications@Marquette. Royal Society of Chmistry does not grant permission for this article to be further copied/distributed or hosted elsewhere without the express permission from Royal Society of Chmistry. 
pronounced, while the other metal-containing samples (PMMA-ZnAl2, PMMA-CoAI2 and PMMA-CuAI2) degrade in two steps. It is interesting to note that the copper-containing systems invariably lead to a decrease in the temperature of the degradation. Unlike the other composites where the presence of the LDH makes removal of the polymer from the Brabender mixer after the melt blending easier than with the virgin polymer, the copper-containing PMMA samples turn into olive-green ashes when melt blended with PMMA at $185^{\circ} \mathrm{C}$ for 7 min. It was noted in a different experiment that copper aluminum LDH changed color from aqua to an olive-green when the aging temperature was raised from $50^{\circ} \mathrm{C}$ to $80^{\circ} \mathrm{C}$. The XRD patterns of either sample exhibit sharp (003) diffraction peaks whose reflections are indicative of long-range ordering in the stacking dimension. However, the XRD of the $\mathrm{LDH}$ aged at $80^{\circ} \mathrm{C}$ reveals additional small diffraction peaks that were identified as CuO. It is likely that the CuAI2 $\mathrm{LDH}$ undergoes degradation earlier than the other systems, leading to instability of the PMMA-CuAI2 composite.

From the TGA experiments run in a nitrogen environment, the following trends are observed:

At 10\% Mass Loss: PMMA-NiAl2 > PMMA-ZnAl2 PMMA-CoAl2 $>$ PMMA > PMMA-CuAI2

At 50\% Mass Loss: PMMA-CoAl2 PMMA-ZnAl2 > PMMA-NiAl2 $>$ PMMA > PMMA-CUAI2

The above trends also hold when the samples are run in air (Fig. 6 and Table 3). It was noted that the temperatures at $10 \%$ and at $50 \%$ mass loss of PMMA-5\%CoAl2 and PMMA-5\%ZnAl2 systems are not much affected by switching from a nitrogen to an air environment.

\section{Fire properties of PMMA-LDH systems}

The relative flammability of PMMA-LDHs ( $\mathrm{LDH}=\mathrm{ZnAl2}, \mathrm{CoAl} 2$ and NiAl2) was investigated using the cone calorimeter. The parameters of interest are the time to ignition, which is usually smaller for nanocomposites than the virgin polymer, the peak of heat release rate (PHRR) and the percentage reduction in this value caused by permission has been granted for this version to appear in e-Publications@Marquette. Royal Society of Chmistry does not grant permission for this article to be further copied/distributed or hosted elsewhere without the express permission from Royal Society of Chmistry. 
nanocomposite formation, the total heat released, which is usually constant for polymers and their nanocomposites, and the mass loss rate. The change in the peak heat release rate is usually explained by the change in the mass loss rate. The heat release rate curve is usually considered to be the most important parameter to be evaluated in fire retardancy studies. All the data reported here are the average of three determinations and were collected during a single run of the cone for better comparison between the data. The heat release curves for PMMA along with NiAI2, CoAl2 and ZnAl2 at loadings from $1-10 \%$ are presented in Fig. 7 and the summary of the cone data is in Table 4. Data from CuAl2 is not shown here because this system suffered degradation during the melt blending process and it was not possible to obtain enough material to do the complete cone calorimetric analysis. The identity of the divalent metal cation is the major difference between the LDHs examined. At $1 \%$ additive loading, there is no improvement observed in peak heat release rate (PHRR) for all composites relative to virgin PMMA. However, as can be seen in Table 4, the addition of that small amount of additive to the PMMA matrix increases the amount of smoke relative to the virgin polymer. Also, the total heat release or THR of virgin PMMA did not change when the polymer was modified with any of the LDH additives; the polymer will all eventually burn.

Fig. 7(A) compares the 3 LDHs at 5\% loading in PMMA while (B) compares the PMMA systems where $10 \% \mathrm{LDH}$ was incorporated. At $5 \%$ LDH loading, PMMA-ZnAl2 and PMMA- CoAl2 show small reductions while no reduction is noted for the PMMA-NiAl2 system. At $10 \% \mathrm{LDH}$ loading though, a larger reduction is observed for the PMMA-CoAl2 system as indicated in Table 4, followed by the PMMAZnAl2 system. The best reduction in PHRR (41\%) was found with the PMMA-10\% CoAl2 system, and PMMA-10\% ZnAl2 system gave a $26 \%$ reduction while the smallest reduction, $16 \%$, was obtained with the PMMA-10\% NiAI2 system. For PMMA-MMT nanocomposites, the best reduction in PHRR that has been seen is about $30 \%,{ }^{35}$ so the poorlydispersed LDH microcomposite is similar to a well-dispersed MMT. In previous work on PMMA- LDH in this laboratory, an LDH of magnesium aluminum modified with 4-styrene sulfonate gave a reduction of $33 \%$ in the PHRR. ${ }^{36}$ permission has been granted for this version to appear in e-Publications@Marquette. Royal Society of Chmistry does not grant permission for this article to be further copied/distributed or hosted elsewhere without the express permission from Royal Society of Chmistry. 
For the polymer-MMT system, the typical observation is that a microcomposite gives no reduction in the PHRR while when the clay is well-dispersed at the nanometre level, significant reductions are observed. For polymer-MMT, the mechanism is believed to be nanoconfinement, in which the degrading radicals are trapped for a time by the nano-dispersed clay particles, permitting radical recombination reactions and thus spreading out the time of thermal degradation. ${ }^{37}$ It is clear that polymer-LDH systems do not operate by the same mechanism, since poorly-dispersed clay gives a significant reduction in the PHRR, but the exact mechanism is still unknown at this time.

Fig. 7(C) shows the effect of the metal ratios $\mathrm{Zn} / \mathrm{Al}$ to the PMMA/LDH produced on PHRR. As can be seen in that figure, ZnAI3 leads to a $35 \%$ reduction in PHRR at $10 \%$ LDH loading (data summarized in Table 5). As can be observed in Table 4 and Table 5, changing the stoichiometry of the divalent to trivalent metal did not have much effect on the PHRR. Both PMMA-10\%ZnAI2 and PMMA$10 \% Z n A l 3$ give approximately $30 \%$ reduction in PHRR. Also, from Table 4 and Table 5, the reductions in PHRR recorded when using the zinc containing LDHs to modify PMMA are larger than those obtained from the PMMA-NiAl2 system, but all systems are inferior to the PMMA-CoAI2 system.

With MMT-containing nanocomposites, the reduction in PHRR is attributed to the change in the mass loss rate (AMLR).25 With the PMMA-LDH composites, there is comparability between the reduction in the PHRR and that of the mass loss, indicating that it is likely that the same explanation applies to the LDHs.

In Fig. 8 , the $\%$ reduction is plotted against the $\%$ additive loading and the system identity. Clearly, the identity of the LDH, in other words, the identity of the divalent metal cation in the LDH, influences the reduction in PHRR of the polymer composite. There is a gradual reduction in PHHR for nickel-containing composites while the improvement is stronger going from $1 \%$ to $5 \%$ additive for cobalt and zinc containing samples.

To simplify the interpretation of cone calorimetric data, indices have been introduced to assess the hazard of developing fires, such as

Journal of Materials Chemistry, Vol. 18, No. 26 (2008): pg. 3091-3102. DOI. This article is @ Royal Society of Chmistry and permission has been granted for this version to appear in e-Publications@Marquette. Royal Society of Chmistry does not grant permission for this article to be further copied/distributed or hosted elsewhere without the express permission from Royal Society of Chmistry. 
the FIGRA (fire growth rate $=$ PHRR/time to PHRR) ${ }^{38}$ and the fire performance index, ${ }^{39} \mathrm{FPI}\left(\mathrm{s} \mathrm{m}^{2} \mathrm{~kW}\right)$, defined as the ratio of time to ignition to the peak rate of heat release. It has been suggested that this parameter relates to the time to flashover (or the time available for escape) in a full-scale fire situation. ${ }^{40}$ An increase in FPI and a decrease in FIGRA indicate reduced fire risk. The FPI and FIGRA of PMMA-10\% LDH systems and the pure polymers are provided in Table 6. One can note that for both indices, the PMMA-CoAI2 system perform better relative to the other LDH systems and also to the virgin polymer. FIGRA shows an improvement for all PMMA-LDH systems but for FPI only the PMMA-CoAI2 system is different from that of virgin PMMA. It is however worth mentioning that these indices concentrate the relevant information into a single number, which is clearly an oversimplification and can be misleading. ${ }^{38}$ It must be noted that FPI has been defined as the inverse of what is shown here by some authors, i.e., PHRR/ $t_{\text {ign. }}{ }^{41}$ The only effect of this is to change the definition of what is an improvement.

Fig. 9 shows the char remaining for each of these samples at a $10 \%$ additive loading. ZnAl3 has more char relative to copper-and nickel-containing samples while the PMMA-CoAl2 char after complete burning of the sample is also appreciable. Only one sample of PMMA$10 \%$ CuAl2 was burned for comparison with other samples, and the results of that one run were not included in the summary table. (Usually, for a cone experiment, 3 samples are run and their average reported.) However, from this single run, the PHRR was observed to match pure PMMA and, as shown in Fig. 9, there is a very small amount of char formed at the end of the run. The ZnAl3 and CoAl2 systems favor the char formation processes while other systems studied were less effective. As can be seen in Fig. 9, the PMMA-10\% ZnAl3 char is compact and covers the whole surface of the aluminum foil. PMMA-10\% CoAI2 system also has a substantial amount of char but less than is seen for ZnAl3. Only small particles spread out on the aluminum foil are visible in the PMMA-10\%CuAl2 char and PMMA$10 \%$ NiAl2 char. ZnAl2 did not produce significant char (picture not included as it was very similar to PMMA-10\%NiAI2), and it was then possible that both the stoichiometry difference and the presence of excess organic found in $\mathrm{ZnAl3}$, but not in $\mathrm{ZnAl2}$, effect the nature of the product obtained after cone calorimetry. More work needs to be permission has been granted for this version to appear in e-Publications@Marquette. Royal Society of Chmistry does not grant permission for this article to be further copied/distributed or hosted elsewhere without the express permission from Royal Society of Chmistry. 
done on this topic. The mass of the char remaining after the cone run is not reported as it is less that $2 \mathrm{~g}$ for all samples and the balance on the instrument has $\pm 1 \mathrm{~g}$ accuracy.

It is known that hydrotalcite-like materials can be used as precursors of high specific surface area mixed oxides. ${ }^{42}$ Because an LDH contains both divalent and trivalent metal cations, spinel structures are formed along with the oxide of the metal present above the stoichiometric value to form AB204 species. ${ }^{43}$ The XRD plots of the char of PMMA-LDHs (10\% additive loadings) after burning in the cone calorimeter and the same char calcined at $1000^{\circ} \mathrm{C}$ for $12 \mathrm{~h}$ are provided in Fig. 10,11, 12 and 13. As can be seen in these figures, the crystallinity of the samples was poor after burning the PMMA-LDH systems and it was difficult to correctly assign the different phases observed in the XRD patterns of these samples. However, after samples were calcinated at $1000^{\circ} \mathrm{C}$ for $12 \mathrm{~h}$, better crystals were obtained as shown in the top XRD traces. ${ }^{44}$

Fig. 10 shows the XRD traces of the char of PMMA-10\%CuAI2 after the cone experiment (bottom) and the same char calcinated at $1000{ }^{\circ} \mathrm{C}$ for $12 \mathrm{~h}$ (top). CuO was the only phase that could be identified after the cone experiment, but after calcination, both CuO and CuAl2O4 phases were indexed. Fig. 11 shows that the XRD traces of the PMMA-10\%ZnAl3 char after the cone experiment was mainly $\mathrm{ZnO}$. The poor crystallinity of this phase does not allow the identification of other phases. However, after calcination of this char at $1000^{\circ} \mathrm{C}$, the crystallinity of the phase is improved and both $\mathrm{ZnO}$ and $\mathrm{ZnAl}_{2} \mathrm{O}_{4}$ phases can be identified.

From Fig. 12, it is noted that the char of PMMA-10\% NiAl2 after the cone experiment matched $\mathrm{NiO}$ and when this char was heated to $1000^{\circ} \mathrm{C}$, both the metal oxide and the spinel phase could be indexed as noted on the figure. Of particular interest is the PMMA-CoAl2 char (Fig. 13). After the cone experiment, the material did not match $\mathrm{CoO}$ as in other PMMA-LDH samples, but a less crystalline phase, close to both $\mathrm{CoAl}_{2} \mathrm{O}_{4}$ and $\mathrm{Co}_{2} \mathrm{AlO}_{4}$ was observed. Due to the poor crystallinity of this phase, we cannot rule out the presence of $\mathrm{CO}_{3} \mathrm{O}_{4}$, a phase that is more stable than $\mathrm{CoO}$ in the presence of oxygen below $1000{ }^{\circ} \mathrm{C} .45$ Ulibarri et al. reported that a hydrotalcite-like compound (CoAl-CO3 permission has been granted for this version to appear in e-Publications@Marquette. Royal Society of Chmistry does not grant permission for this article to be further copied/distributed or hosted elsewhere without the express permission from Royal Society of Chmistry. 
LDH) with oxidizable cations shows an exothermic effect at $568 \mathrm{~K}$ in the DTA patterns which are associated with a Co (II) / Co(III) oxidation process, since this event was not observed when the analysis was carried out in nitrogen. ${ }^{42}$ When calcined at $1000^{\circ} \mathrm{C}$, the peaks obtained for their samples were matched with $\mathrm{Co}_{3} \mathrm{O}_{4}, \mathrm{CoAl}_{2} \mathrm{O}_{4}$ and/or $\mathrm{CO}_{2} \mathrm{AlO}_{4}$. In this study, the presence of $\mathrm{CO}_{2} \mathrm{AlO}_{4}$ spinel is supported by the mass remaining from the TGA experiment (run in a nitrogen environment) where a final total mass loss of $56 \%$ is observed. This compares well with the expected mass loss of $57 \%$, based on formation of the spinel $\mathrm{CO}_{2} \mathrm{AlO} 4$ as the final product; the formation of $\mathrm{CoAl}_{2} \mathrm{O}_{4}$ would suggest a final mass loss of $63 \%$.

\section{Conclusions}

Layered double hydroxides CoAl2, NiAl2, CuAl2, ZnAl2 and ZnAl3 were synthesized using the co-precipitation method. The mechanical properties, the thermal stability, and the fire properties of their PMMA nanocomposites were examined. FT-IR and XRD measurements show that the undecenoate anions were incorporated between the layers of these materials. XRD measurements of PMMALDHs suggest that an intercalated system is obtained for CoAl2 while the other LDHs lead to immiscible systems. TEM images of these samples also show good dispersion for CoAl2 while poor dispersion is noted for the other samples. The thermal stability of PMMA is improved by the presence of these LDHs. The cone experiment shows that the cobalt-containing LDH improves the PHRR of PMMA where the best reduction obtained was $41 \%$, better than has been seen in PMMA-MMT nanocomposites. XRD of the char of PMMA-LDH obtained after cone calorimetry and after calcination of the char at $1000^{\circ} \mathrm{C}$ supports the formation of both spinel and metal (II) oxides. The tensile tests of the PMMA-LDH systems reveal that combining these layered materials with PMMA does not change the mechanical properties of the polymer. It is significant to call attention to the difference between LDHs and MMTs. For MMT, a microcomposite will give no change in the peak heat release rate and cause deterioration in the mechanical properties but for LDHs microcomposite formation gives a rather substantial reduction in PHRR and no significant change in mechanical properties. These observations suggest that there are quite different systems and permission has been granted for this version to appear in e-Publications@Marquette. Royal Society of Chmistry does not grant permission for this article to be further copied/distributed or hosted elsewhere without the express permission from Royal Society of Chmistry. 
NOT THE PUBLISHED VERSION; this is the author's final, peer-reviewed manuscript. The published version may be accessed by following the link in the citation at the bottom of the page.

are likely to function by different pathways. Further work is underway to elucidate these pathways.

\section{Notes}

*. See electronic supplementary information (ESI) at http://epublications.marquette.edu/chem fac/10/.

\section{Acknowledgements}

This work was performed under the sponsorship of the US Department of Commerce, National Institute of Standards and Technology, Grant 60 NANB6D6018. The XRD measurements were kindly carried out by Dr Sergey Lindeman.

\section{References}

1. M. Alexandre and P. Dubois, Mater. Sci. Eng., R, 2000, 28,1.

2. F. Cavani, F. Trifiro and A. Vaccari, Catal. Today, 1991, 11, 173.

3. T. Hibino and W. Jones, J. Mater. Chem., 2001, 11, 1321.

4. Z. Liu, R. Ma, M. Osada, N. Iyi, Y. Ebina, K. Takada and T. Sasaki, J. Am. Chem. Soc., 2006, 128, 4872

5. G. A. Wang, C. C. Wang and C. Y. Chen, Polymer, 2005, 46, 5065.

6. (a) W. Chen and B. Qu, Chem. Mater., 2003, 15, 3208; (b) B. P. Messersmith and S. I. Stupp, Chem. Mater., 1995, 7, 454; (c) W. Chen, F. Feng and B. Qu, Chem. Mater., 2004, 16, 368.

7. F. Kooli, I. C. Chisem, M. Vucelic and W. Jones, Chem. Mater., 1996, 8, 1969.

8. W. Hofmeister and H. Von Platen, Cryst. Rev., 1992, 3, 3; C. Bender-Koch, Hyperfine Interact., 1998, 117, 131.

9. D. L. Bish, Bull. Mineral, 1980, 103, 170.

10. S. Miyata, Clays Clay Miner., 1983, 31, 305; K. Chibwe and W. Jones, J. Chem. Soc., Chem. Commun., 1989, 14, 926.

11. W. T. Reichle, S. Y. Kang and D. S. Evehardt, J. Catal., 1986, 101, 352.

12. V. R. L. Constantino and T. J. Pinnavaia, Inorg. Chem., 1995, 34, 883.

13. W. Chen, L. Feng and B. Qu, Chem. Mater., 2004, 16, 3208.

14. M. Tanaka, I. Y. Park, K. Kuroda and C. Kato, Bull. Chem. Soc. Jpn., $1989,62,3442$.

Journal of Materials Chemistry, Vol. 18, No. 26 (2008): pg. 3091-3102. DOI. This article is (C) Royal Society of Chmistry and permission has been granted for this version to appear in e-Publications@Marquette. Royal Society of Chmistry does not grant permission for this article to be further copied/distributed or hosted elsewhere without the express permission from Royal Society of Chmistry. 
NOT THE PUBLISHED VERSION; this is the author's final, peer-reviewed manuscript. The published version may be accessed by following the link in the citation at the bottom of the page.

15. E. M. Moujahid, J. P. Besse and F. Leroux, J. Mater. Chem., 2002, 12, 3324; C. O. Oriakhi, I. V. Farr and M. M. Lerner, Clays Clay Miner., 1997, 45, 194.

16. S. Carlino, Solid State Ionics, 1997, 98, 73; Z. B. Hussein, Z. Zainal and C. Y. Ming, J. Mater. Sci. Lett., 2000, 19, 879; S. Rey, J. MeridaRobles, K. S. Han, L. Guerlou-Demourgues, C. Delmas and E. Duguet, Polym. Int., 1999, 48, 277.

17. F. Leroux and J. Besse, Chem. Mater., 2001, 13, 3507.

18. P. Aranda and E. Ruiz-Hitzky, Chem. Mater., 1992, 4, 1395.

19. F. Kooli, V. Rives, M. A. Ulibarri and W. Jones, Mater. Res. Soc. Symp. Proc., 1995, 371, 143.

20. K. T. Ehlsissen, A. Delahaye-Vidal, P. Genin, M. Figlarz and P. Willmann, J. Mater. Chem.,

1993, 3, 883; X. M. Liu, Y. H. Zhang, X. G. Zhang and S. Y. Fu, Electrochim. Acta, 2004, 49, 3137.

21. S. Friberg, R. Thundathil and J. Stoffer, Science, 1979, 205, 607.

22. J. Zhang, D. J. Jiang, D. Wang and C. A. Wilkie, Polym. Degrad. Stab., 2006, 91, 2665; S. Su and C. A. Wilkie, J. Polym. Sci., Part A: Polym. Chem., 2003, 41, 1124 .

23. K. Kuma, W. Paplawsky, B. Gedulin and G. Arrhenius, Origins Life Evol. Biosphere, 1989, 19, 573.

24. T. Hibino, Chem. Mater., 2004, 16, 5482.

25. J. W. Gilman, T. Kashiwagi, M. Nyden, J. E. T. Brown, C. L. Jackson, S. Lomakin, E. P. Giannelis, E. Manias, in Chemistry and Technology of Polymer Additives, ed. S. Al-Malaika, A. Golovoy, C. A. Wilkie, Blackwell Scientific, Oxford, 1999, pp. 249.

26. U. Costantino, F. Marmottini, M. Nocchetti and R. Vivani, Eur. J. Inorg. Chem., 1998, 10, 1439.

27. M. Borja and P. K. Dutta, J. Phys. Chem., 1992, 96, 5434; Z. P. Xu, P. S. Braterman, K. Yu, H. Xu, Y. Wang and C. J. Brinker, Chem. Mater., 2004, 16, 2750.

28. J. T. Kloprogge and R. L. Frost, J. Solid State Chem., 1999, 146, 506.

29. Z. P. Xu, P. S. Braterman and N. Seifollah, Abstact in Proceedings of the 224 th ACS National Meeting, Boston, MA, Aug. 18-22, 2002, 219.

Journal of Materials Chemistry, Vol. 18, No. 26 (2008): pg. 3091-3102. DOI. This article is @ Royal Society of Chmistry and permission has been granted for this version to appear in e-Publications@Marquette. Royal Society of Chmistry does not grant permission for this article to be further copied/distributed or hosted elsewhere without the express permission from Royal Society of Chmistry. 
30. A. De Roy, C. Forano, K. El Malki, J. P. Besse, in Synthesis of Microporous Materials, ed. M. L. Ocelli, H. E. Robson, Van Nostrand Reihold, New York, 1992, Vol. 2, pp. 108.

31. J. A. Chandrasiri and C. A. Wilkie, Polym. Degrad. Stab., 1994, 45, 91; D. Wang, J. Zhu, Q. Yao and C. A. Wilkie, Chem. Mater., 2002, 14, 3837.

32. W. Chen, L. Feng and B. Qu, Solid State Commun., 2004, 130, 259.

33. T. Kashiwagi, A. Inaba, J. E. Brown, K. Hatada, T. Kitayama and E. Masuda, Macromolecules, 1986, 19, 2160.

34. B. J. Holland and J. N. Hay, Polym. Degrad. Stab., 2002, 77, 435.

35. P. Jash and C. A. Wilkie, Polym. Degrad. Stab., 2005, 88, 401.

36. M. C. Costache, D. Wang, M. J. Heidecker, E. Manias and C. A. Wilkie, Polym. Adv. Technol., 2006, 17, 272.

37. K. Chen, C. A. Wilkie and S. Vyazovkin, J. Phys. Chem. B, 2007, 111, 12685; M. C. Costache, M. J. Heidecker, E. Manias, G. Camino, Frache, G. R. K. Gupta and C. A. Wilkie, Polymer, 2007, 48, 6532.

38. B. Schartel and T. R. Hull, Fire Mater., 2007, 31, 327.

39. M. Zanetti, G. Camino, D. Cavanese, A. B. Morgan, F. J. Lamelas and C. A. Wilkie, Chem. Mater., 2002, 14, 189.

40. M. M. Hirschler, S. Shakir, Proceedings from Flame Retardants 92, Elsevier Applied Science, London/New York, 1992.

41. U. Constantino, A. Gallipoli, M. Nocchetti, G. Camino, F. Bellucci and A. Frache, Polym. Degrad. Stab., 2005, 90, 586.

42. M. A. Ulibarri, J. M. Ferna' 'ndez, F. M. Labajos and V. Rives, Chem. Mater., 1991, 3, 626.

43. T. Sato, K. Kato, T. Endo and M. Shimada, React. Solids, 1986, 2, 253; T. Sato, H. Fujita, T. Endo and M. Shimada, React. Solids, 1988, 5, 219.

44. Powder Diffraction File Alphabetical Indexes, Inorganic Phases, JCPDS, International Centre for Diffraction Data, Swartmore, PA, 1999.

45. B. Basavalingu, J. A. K. Tareen and G. T. Bhandage, J. Mater. Sci. Lett., 1986, 5, 1227.

Journal of Materials Chemistry, Vol. 18, No. 26 (2008): pg. 3091-3102. DOI. This article is @ Royal Society of Chmistry and permission has been granted for this version to appear in e-Publications@Marquette. Royal Society of Chmistry does not grant permission for this article to be further copied/distributed or hosted elsewhere without the express permission from Royal Society of Chmistry. 
NOT THE PUBLISHED VERSION; this is the author's final, peer-reviewed manuscript. The published version may be accessed by following the link in the citation at the bottom of the page.

\section{Appendix}

Figure 1: TGA and DTG of the pristine LDHs $\left(20^{\circ} \mathrm{C} \mathrm{min}^{-1}, \mathrm{~N} 2\right): \mathrm{ZnAl} 2$ and ZnAl3 (A); NiAl2 (B); CuAl2 (C) and CoAl2 (D).
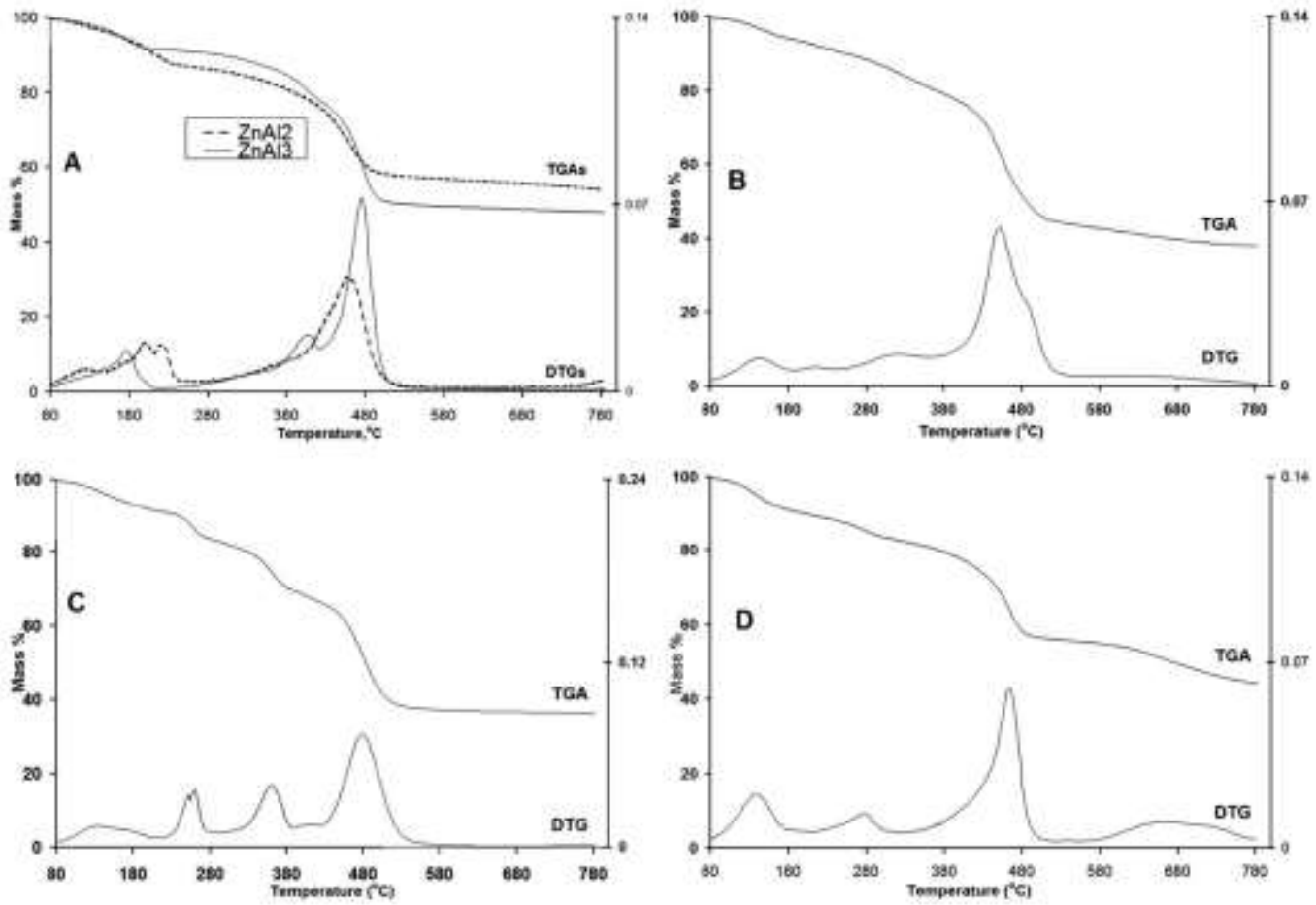

Journal of Materials Chemistry, Vol. 18, No. 26 (2008): pg. 3091-3102. DOI. This article is @ Royal Society of Chmistry and permission has been granted for this version to appear in e-Publications@Marquette. Royal Society of Chmistry does not grant permission for this article to be further copied/distributed or hosted elsewhere without the express permission from Royal Society of Chmistry. 
NOT THE PUBLISHED VERSION; this is the author's final, peer-reviewed manuscript. The published version may be accessed by following the link in the citation at the bottom of the page.

Figure 2: XRD of LDH and their PMMA-LDHs systems obtained by melt blending ( $185^{\circ} \mathrm{C}$ for $7 \mathrm{~min}$ ). Commercial PMMA, typical Mw 120 000, $\left.\operatorname{Tg} 99.0^{\circ} \mathrm{C}\right)$.
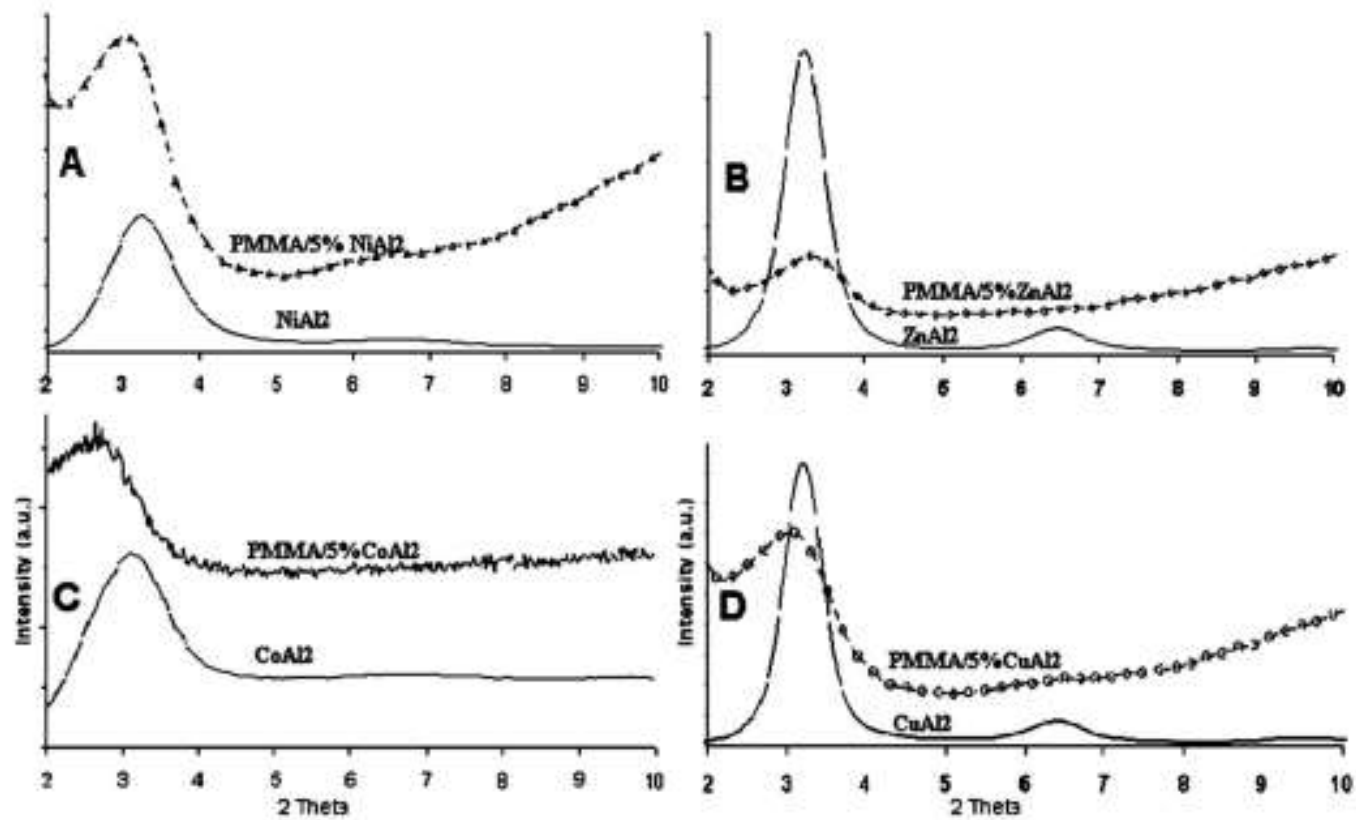

Journal of Materials Chemistry, Vol. 18, No. 26 (2008): pg. 3091-3102. DOI. This article is (c) Royal Society of Chmistry and permission has been granted for this version to appear in e-Publications@Marquette. Royal Society of Chmistry does not grant permission for this article to be further copied/distributed or hosted elsewhere without the express permission from Royal Society of Chmistry. 
NOT THE PUBLISHED VERSION; this is the author's final, peer-reviewed manuscript. The published version may be accessed by following the link in the citation at the bottom of the page.

Figure 3: TEM images of PMMA-LDHs formed by melt blending; low magnification (left) and higher magnification (right) from top to bottom: (A) PMMA-5\% ZnAl2; (B) PMMA-5\% CoAl2; (C) PMMA-5\% NiAl2; (D) PMMA-5\%ZnAl3.
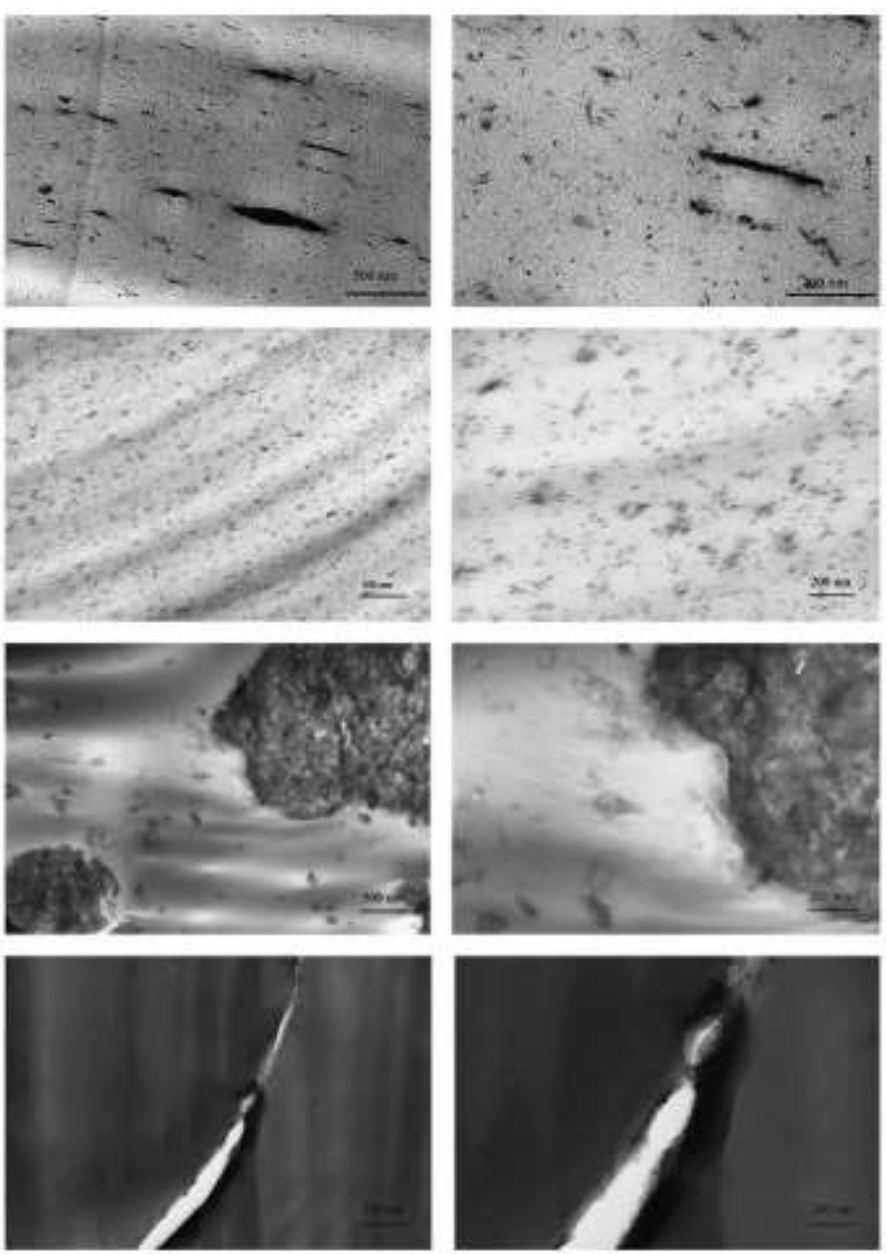

Journal of Materials Chemistry, Vol. 18, No. 26 (2008): pg. 3091-3102. DOI. This article is @ Royal Society of Chmistry and permission has been granted for this version to appear in e-Publications@Marquette. Royal Society of Chmistry does not grant permission for this article to be further copied/distributed or hosted elsewhere without the express permission from Royal Society of Chmistry. 
NOT THE PUBLISHED VERSION; this is the author's final, peer-reviewed manuscript. The published version may be accessed by following the link in the citation at the bottom of the page.

Figure 4: The TGAs of melt blended PMMA-LDH (5\% loading) in N2 at $20{ }^{\circ} \mathrm{C} \min ^{-1}$. ( $\mathrm{A}=\mathrm{PMMA}-\mathrm{CuAl} 2, \mathrm{~B}=\mathrm{PMMA}, \mathrm{C}=\mathrm{PMMA}-\mathrm{ZnAl} 2 \mathrm{D}=$ PMMA-COAI2, $E=$ PMMA-NiAI2).

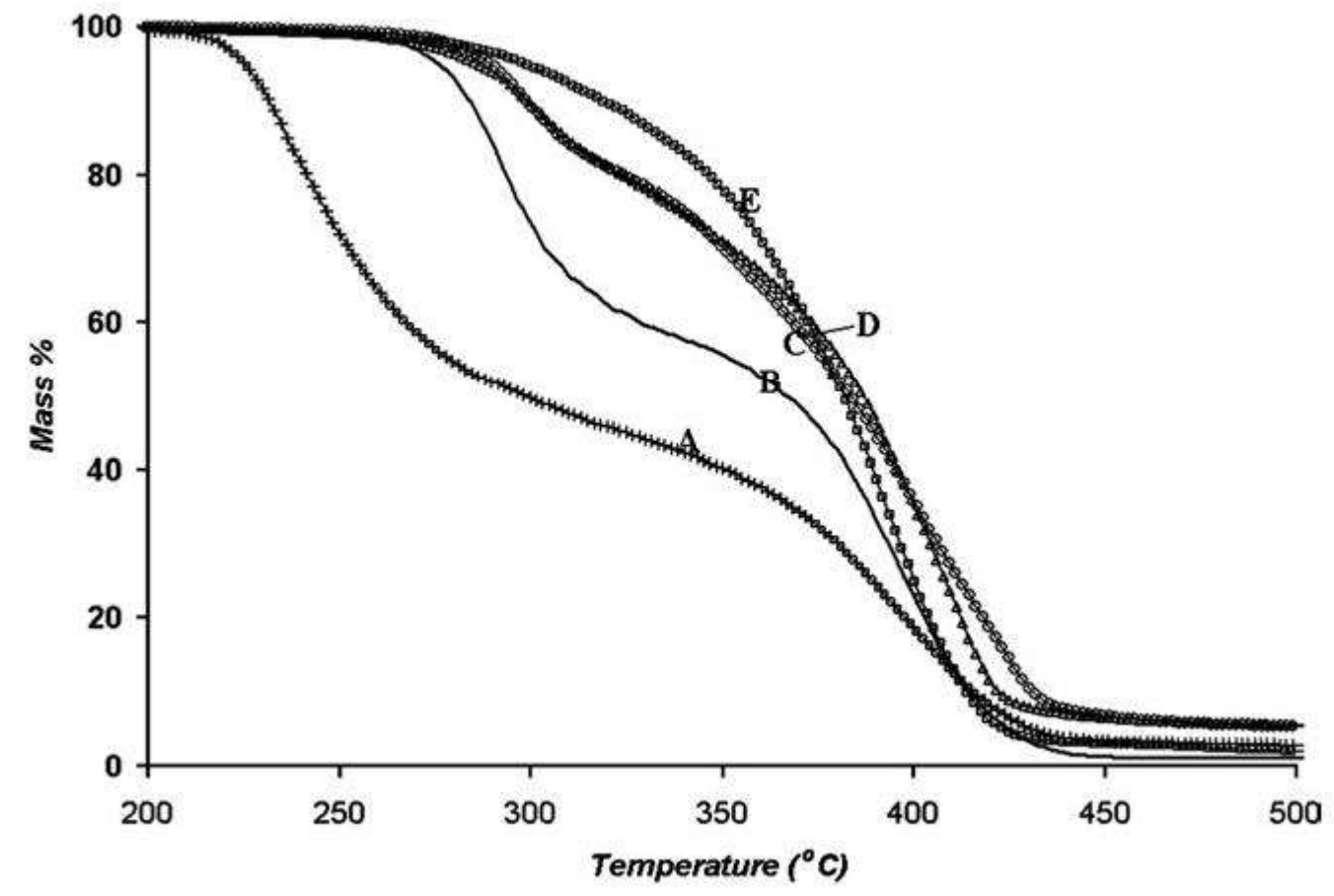

Journal of Materials Chemistry, Vol. 18, No. 26 (2008): pg. 3091-3102. DOI. This article is (C) Royal Society of Chmistry and permission has been granted for this version to appear in e-Publications@Marquette. Royal Society of Chmistry does not grant permission for this article to be further copied/distributed or hosted elsewhere without the express permission from Royal Society of Chmistry. 
NOT THE PUBLISHED VERSION; this is the author's final, peer-reviewed manuscript. The published version may be accessed by following the link in the citation at the bottom of the page.

Figure 5: The TGA curves of melt blended PMMA LDH (10\% loading) in $\mathrm{N} 2$ at $20{ }^{\circ} \mathrm{C} \mathrm{min}^{-1}$. ( $\mathrm{A}=\mathrm{PMMA}$ CuAl2, $\mathrm{B}=\mathrm{PMMA}, \mathrm{C}=\mathrm{PMMA} \mathrm{CoAl}$, $\mathrm{D}=\mathrm{PMMA}$ ZnAl2, $\mathrm{E}=$ PMMA NiAl2).

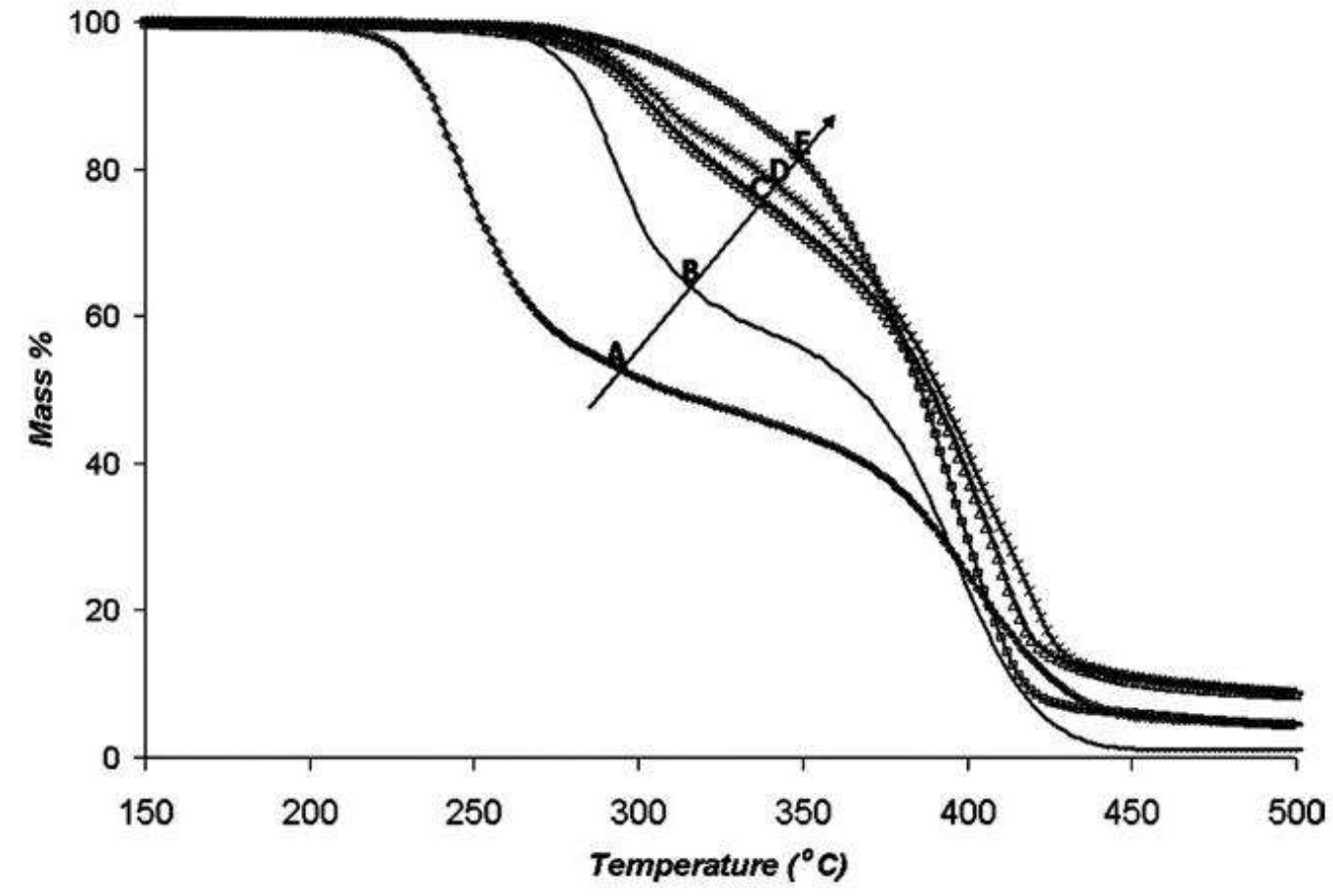

Journal of Materials Chemistry, Vol. 18, No. 26 (2008): pg. 3091-3102. DOI. This article is @ Royal Society of Chmistry and permission has been granted for this version to appear in e-Publications@Marquette. Royal Society of Chmistry does not grant permission for this article to be further copied/distributed or hosted elsewhere without the express permission from Royal Society of Chmistry. 
NOT THE PUBLISHED VERSION; this is the author's final, peer-reviewed manuscript. The published version may be accessed by following the link in the citation at the bottom of the page.

Figure 6: The TGA curves of PMMA-LDH (5\% loading) by melt blending in air at $20^{\circ} \mathrm{C} \mathrm{min}^{-1}$.

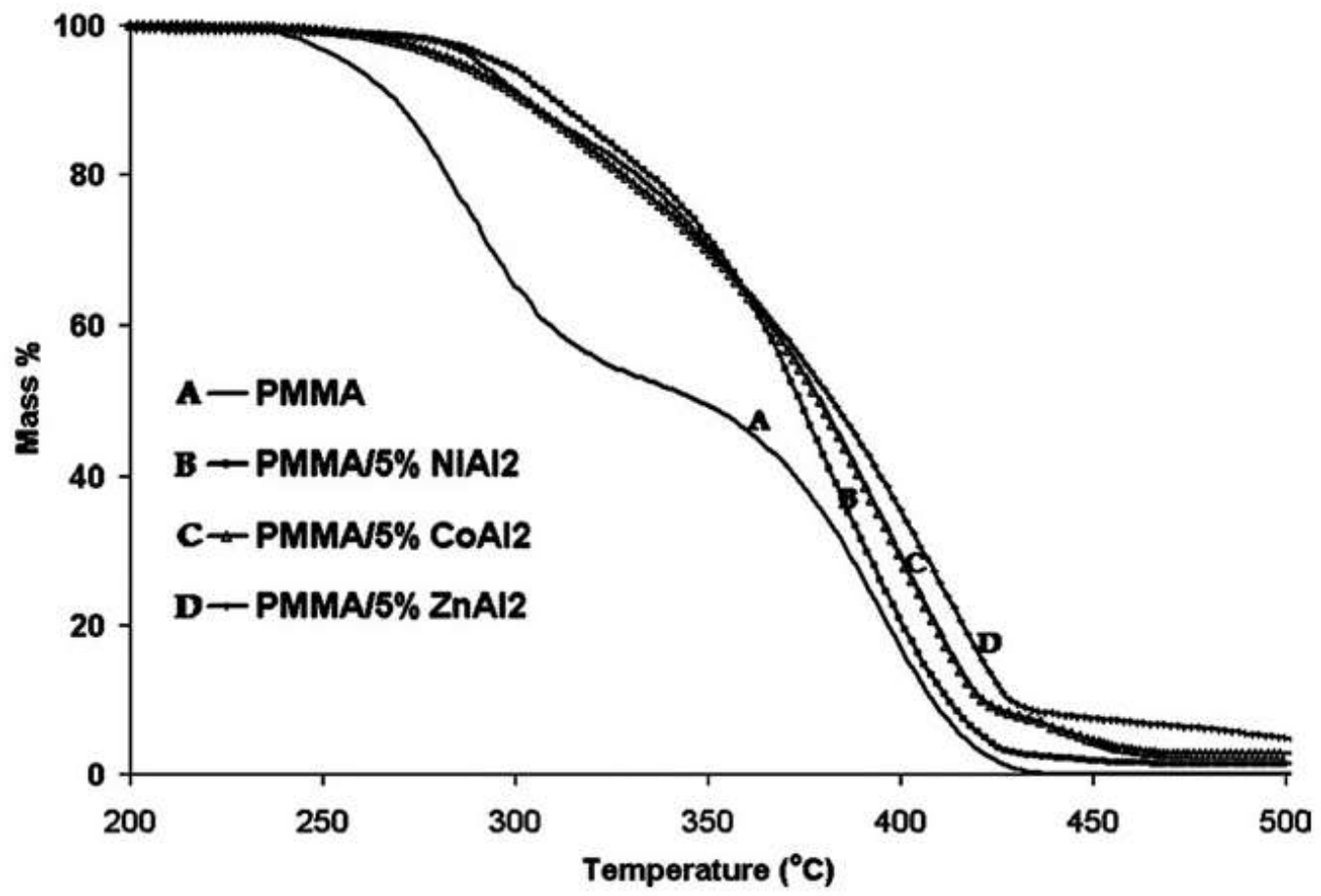

Journal of Materials Chemistry, Vol. 18, No. 26 (2008): pg. 3091-3102. DOI. This article is @ Royal Society of Chmistry and permission has been granted for this version to appear in e-Publications@Marquette. Royal Society of Chmistry does not grant permission for this article to be further copied/distributed or hosted elsewhere without the express permission from Royal Society of Chmistry. 
NOT THE PUBLISHED VERSION; this is the author's final, peer-reviewed manuscript. The published version may be accessed by following the link in the citation at the bottom of the page.

Figure 7: HRR curves of PMMA-LDH at $50 \mathrm{~kW} \mathrm{m-2.} \mathrm{(A)} \mathrm{PMMA-5 \% LDH;}$ (B) PMMA-10\% LDH; (C) PMMA-(1, 5 \& 10\%)ZnAl3 LDH.

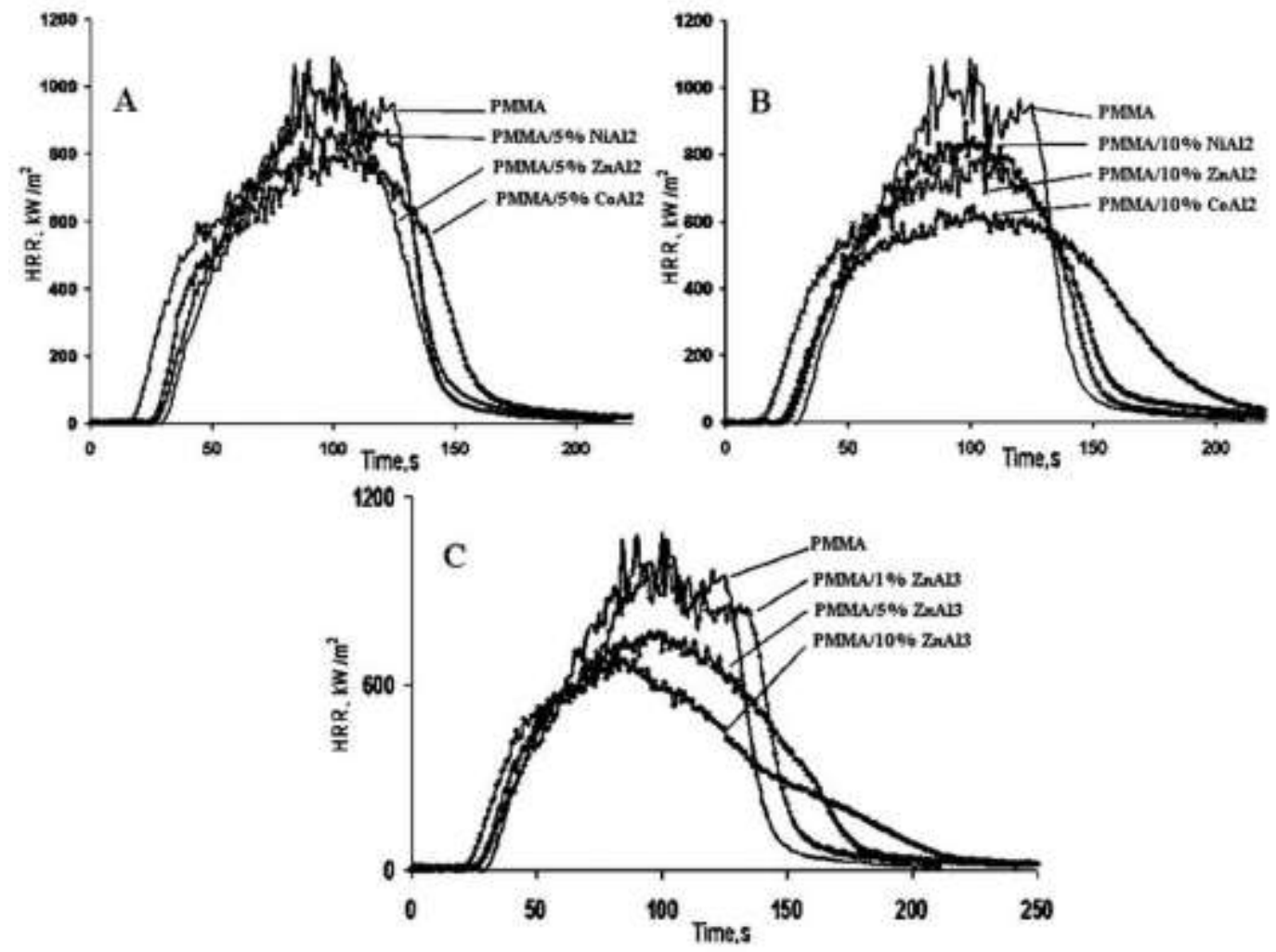

Journal of Materials Chemistry, Vol. 18, No. 26 (2008): pg. 3091-3102. DOI. This article is (C) Royal Society of Chmistry and permission has been granted for this version to appear in e-Publications@Marquette. Royal Society of Chmistry does not grant permission for this article to be further copied/distributed or hosted elsewhere without the express permission from Royal Society of Chmistry. 
NOT THE PUBLISHED VERSION; this is the author's final, peer-reviewed manuscript. The published version may be accessed by following the link in the citation at the bottom of the page.

Figure 8: Comparing the fire properties of different PMMA-LDH systems: \% reduction in PHRR vs. \% LDH loading vs. system identity.

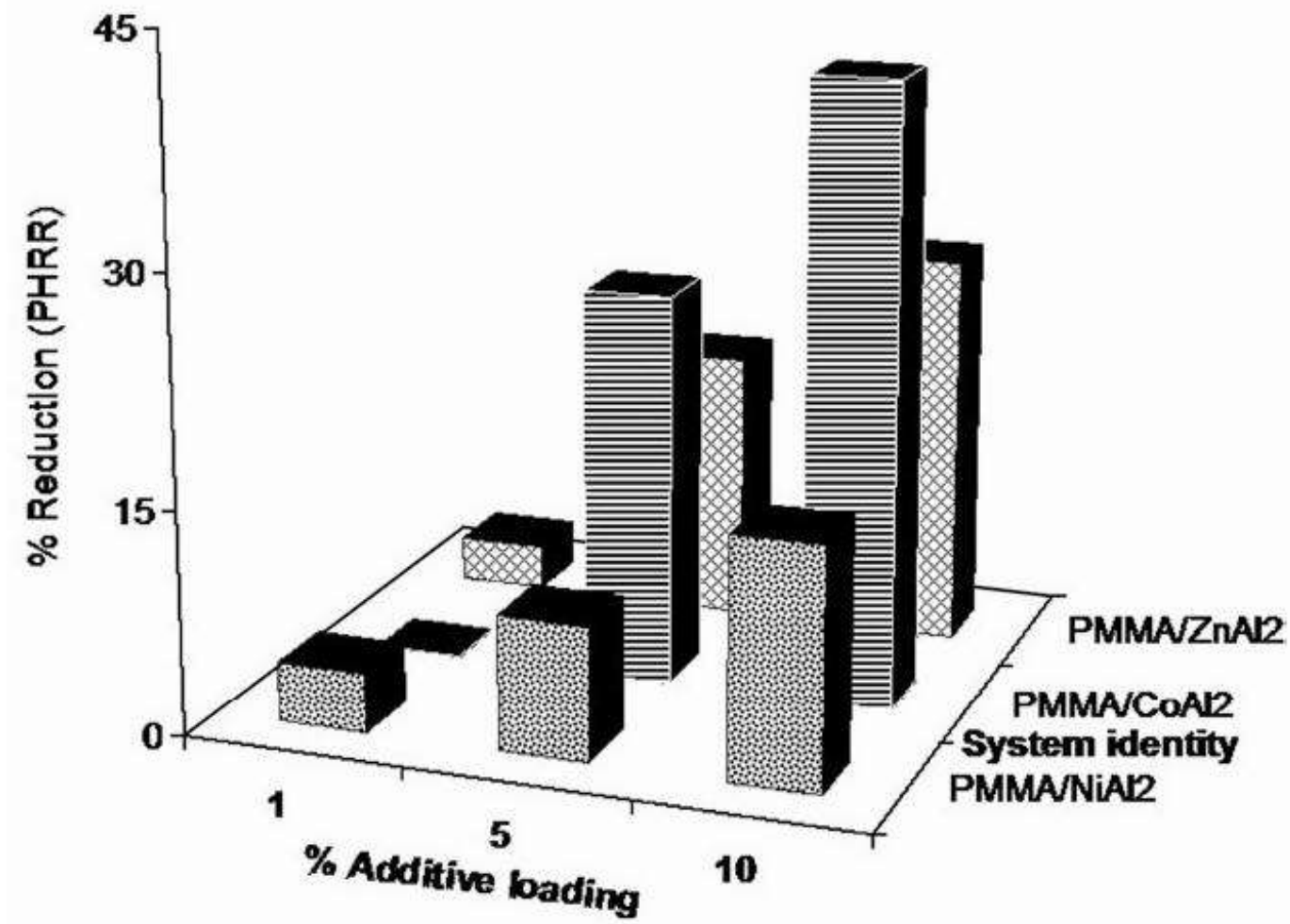

Journal of Materials Chemistry, Vol. 18, No. 26 (2008): pg. 3091-3102. DOI. This article is (c) Royal Society of Chmistry and permission has been granted for this version to appear in e-Publications@Marquette. Royal Society of Chmistry does not grant permission for this article to be further copied/distributed or hosted elsewhere without the express permission from Royal Society of Chmistry. 
NOT THE PUBLISHED VERSION; this is the author's final, peer-reviewed manuscript. The published version may be accessed by following the link in the citation at the bottom of the page.

Figure 9: The char of some $\mathrm{PMMA}^{-1} 0 \% \mathrm{LDH}$ after the cone calorimetry test.

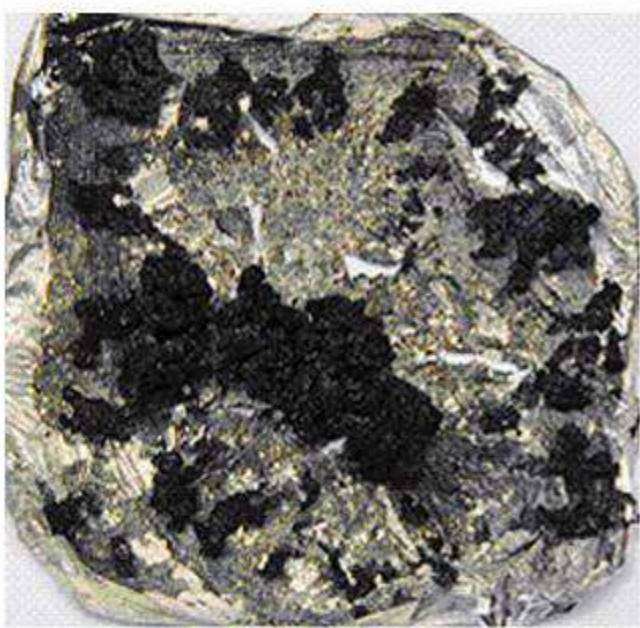

PMIMA $10 \%$ COAl2

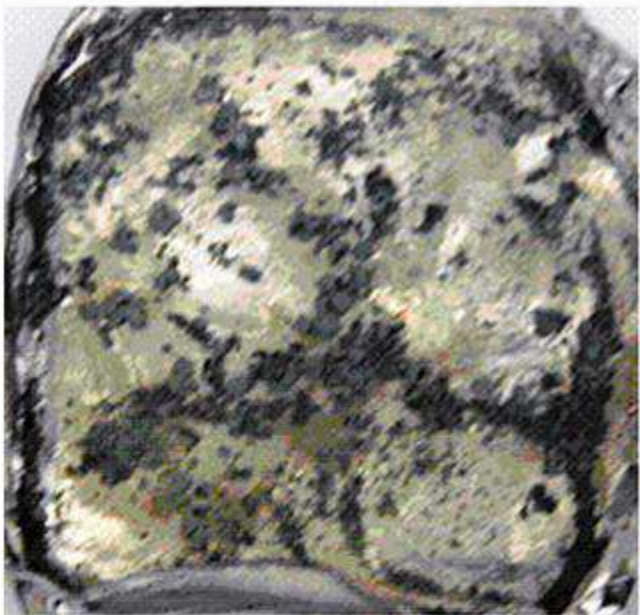

PMIMA/10\% NiAl2

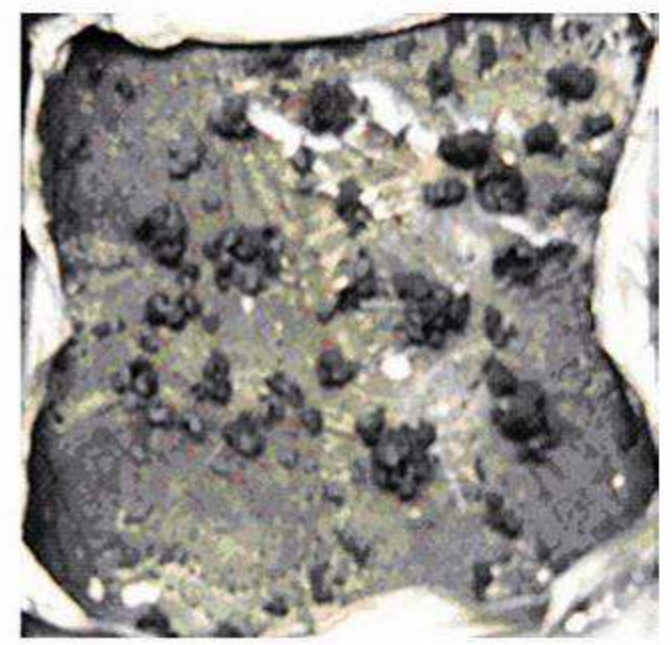

PMIMLA10\% CuAl2

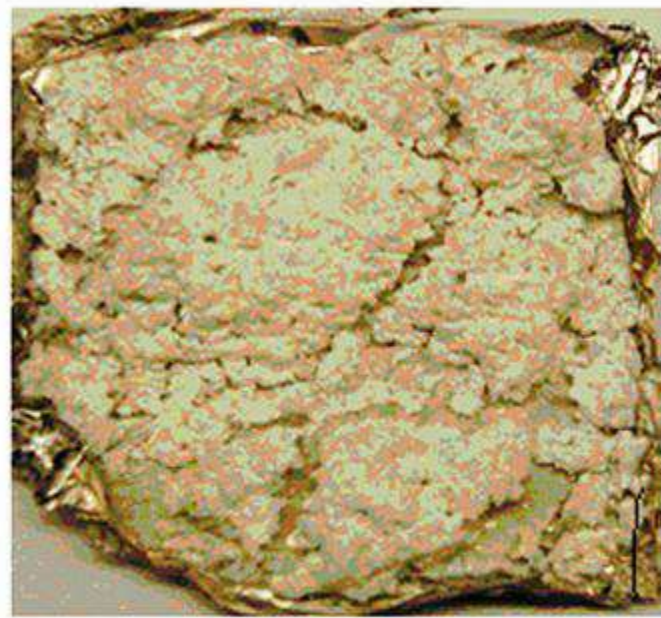

PMIMLA 10\% ZnAl3

Journal of Materials Chemistry, Vol. 18, No. 26 (2008): pg. 3091-3102. DOI. This article is @ Royal Society of Chmistry and permission has been granted for this version to appear in e-Publications@Marquette. Royal Society of Chmistry does not grant permission for this article to be further copied/distributed or hosted elsewhere without the express permission from Royal Society of Chmistry. 
NOT THE PUBLISHED VERSION; this is the author's final, peer-reviewed manuscript. The published version may be accessed by following the link in the citation at the bottom of the page.

Figure 10: $\mathrm{PMMA}-10 \%$ CuAl2 cone char and this char heated to 1000 ${ }^{\circ} \mathrm{C}$ for $12 \mathrm{~h}\left({ }^{\circ} \mathrm{CuO}, \mathrm{PDF} 48-1548\right.$; *CuAl2)4, PDF 48-1548), ref 44.

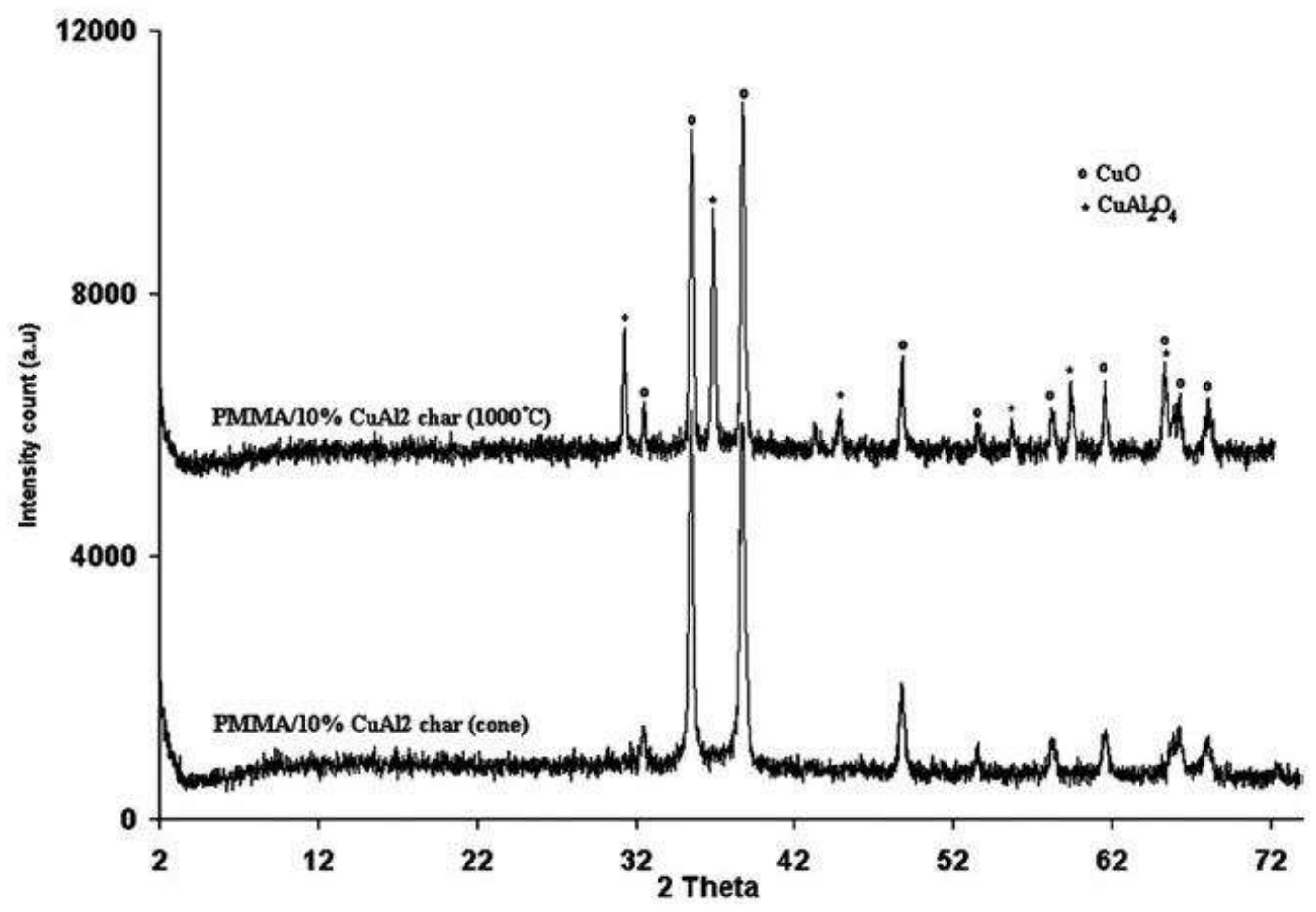

Journal of Materials Chemistry, Vol. 18, No. 26 (2008): pg. 3091-3102. DOI. This article is @ Royal Society of Chmistry and permission has been granted for this version to appear in e-Publications@Marquette. Royal Society of Chmistry does not grant permission for this article to be further copied/distributed or hosted elsewhere without the express permission from Royal Society of Chmistry. 
NOT THE PUBLISHED VERSION; this is the author's final, peer-reviewed manuscript. The published version may be accessed by following the link in the citation at the bottom of the page.

Figure 11: PMMA 10\% ZnAl3 cone char and this char heated to 1000 ${ }^{\circ} \mathrm{C}$ for $12 \mathrm{~h}$ ( ${ }^{\circ} \mathrm{ZnO}$, PDF 36-1451; ZnAl204, PDF 5-0671), ref 39.

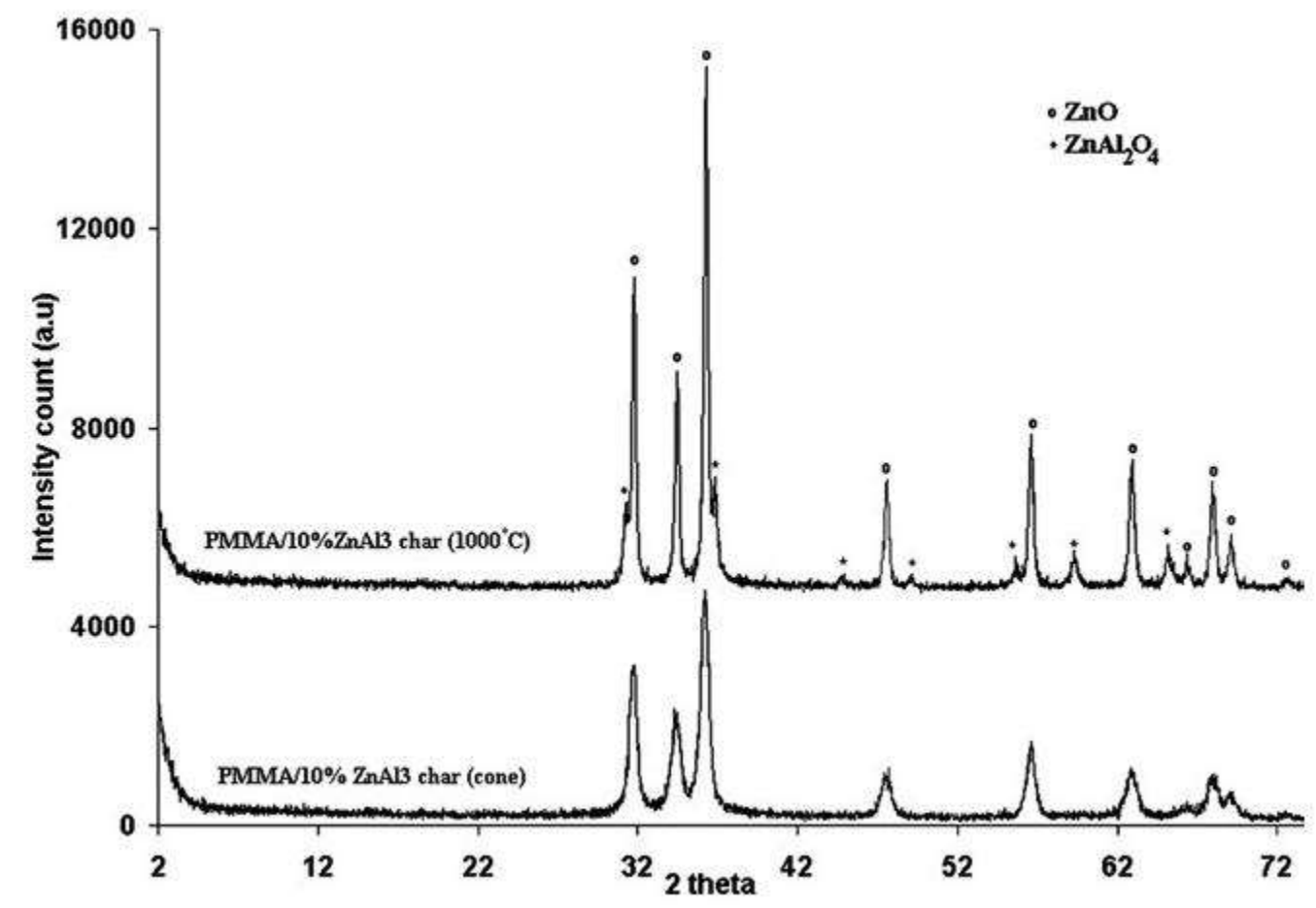

Journal of Materials Chemistry, Vol. 18, No. 26 (2008): pg. 3091-3102. DOI. This article is (C) Royal Society of Chmistry and permission has been granted for this version to appear in e-Publications@Marquette. Royal Society of Chmistry does not grant permission for this article to be further copied/distributed or hosted elsewhere without the express permission from Royal Society of Chmistry. 
NOT THE PUBLISHED VERSION; this is the author's final, peer-reviewed manuscript. The published version may be accessed by following the link in the citation at the bottom of the page.

Figure 12: PMMA $10 \%$ NiAl2 cone char and this char heated to 1000 ${ }^{\circ} \mathrm{C}$ for $12 \mathrm{~h}$ ( ${ }^{\circ} \mathrm{NiO}, \mathrm{PDF} 47-1049 ;{ }^{*} \mathrm{NiAl} 2 \mathrm{O} 4$ Nickel Aluminate, PDF 10339), ref 39.

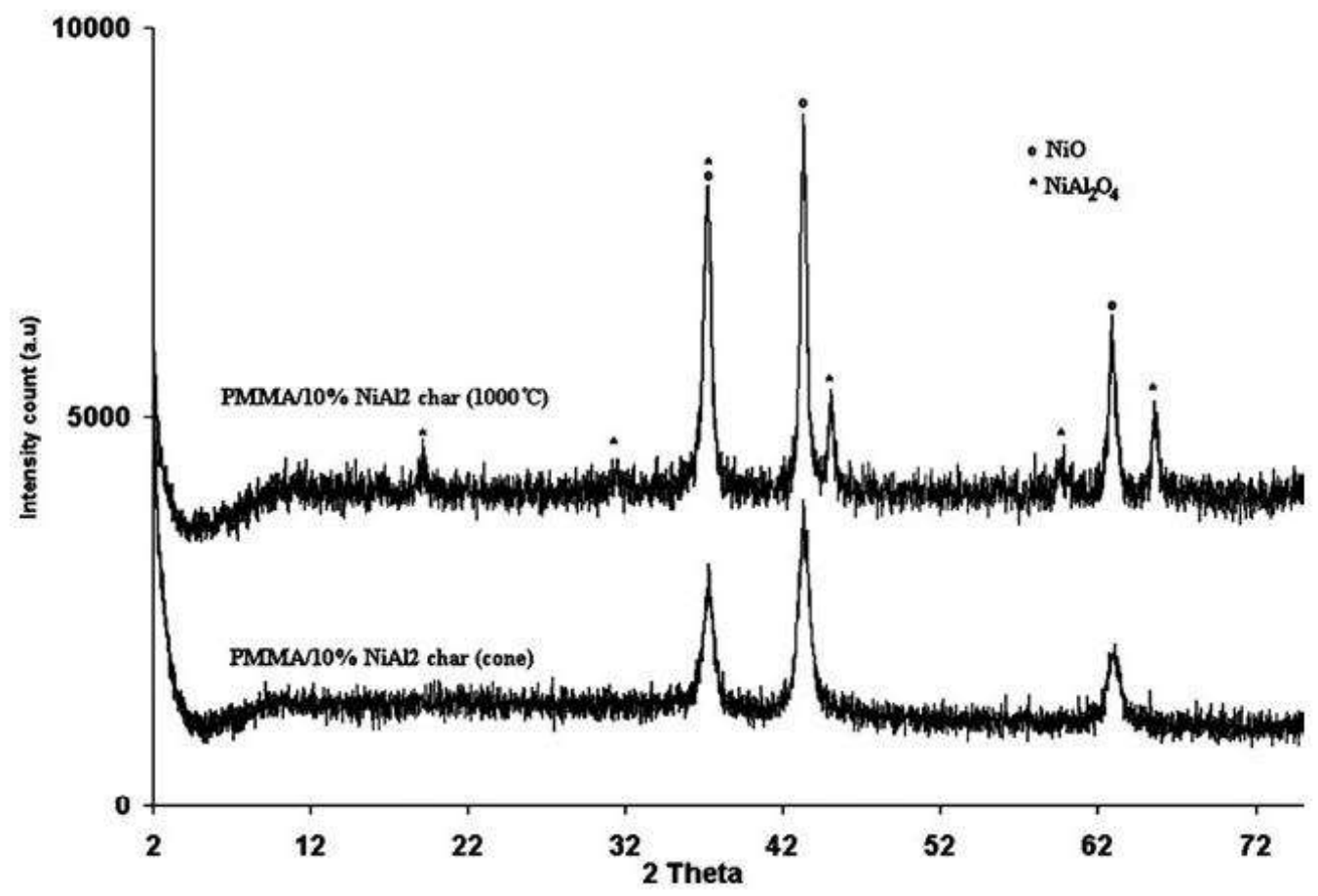

Journal of Materials Chemistry, Vol. 18, No. 26 (2008): pg. 3091-3102. DOI. This article is @ Royal Society of Chmistry and permission has been granted for this version to appear in e-Publications@Marquette. Royal Society of Chmistry does not grant permission for this article to be further copied/distributed or hosted elsewhere without the express permission from Royal Society of Chmistry. 
NOT THE PUBLISHED VERSION; this is the author's final, peer-reviewed manuscript. The published version may be accessed by following the link in the citation at the bottom of the page.

Figure 13: PMMA 10\%CoAl2 cone char and this char heated to 1000 ${ }^{\circ} \mathrm{C}$ for $12 \mathrm{~h}$ (char correspond to probably CoAl2O4, PDF 44-160 and/or Co2AIO4, PDF 38-814, and/or Co304, PDF 43-1003, ref 39.

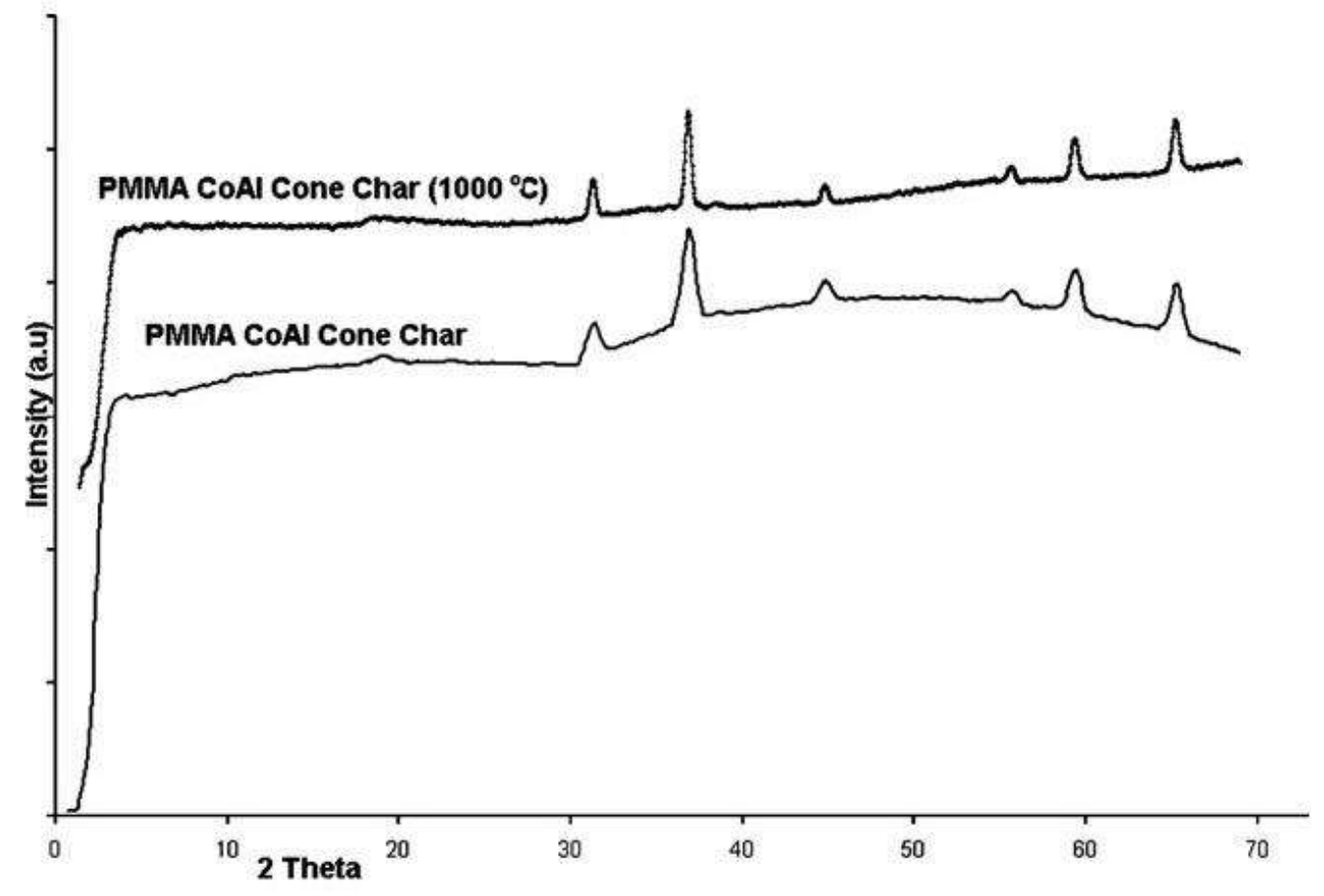

Journal of Materials Chemistry, Vol. 18, No. 26 (2008): pg. 3091-3102. DOI. This article is (C) Royal Society of Chmistry and permission has been granted for this version to appear in e-Publications@Marquette. Royal Society of Chmistry does not grant permission for this article to be further copied/distributed or hosted elsewhere without the express permission from Royal Society of Chmistry. 
Table 1: Tensile properties of PMMA-LDHs systems

\begin{tabular}{llll}
\hline Material & $\begin{array}{l}\text { Tensile } \\
\text { strength/MPa }\end{array}$ & $\begin{array}{l}\text { Elongation of } \\
\text { break (\%) }\end{array}$ & $\begin{array}{l}\text { Young's } \\
\text { Modulus/GPa }\end{array}$ \\
\hline PMMA & $27 \pm 8.4$ & $2.4 \pm 0.3$ & $1.1 \pm 0.4$ \\
PMMA 5\% NiA12 & $35 \pm 4.4$ & $2.9 \pm 0.4$ & $1.2 \pm 0.2$ \\
PMMA 10\%NiA12 & $26 \pm 5.8$ & $2.7 \pm 0.4$ & $1.0 \pm 0.3$ \\
PMMA 5\% CoA12 & $25 \pm 6.8$ & $2.2 \pm 0.3$ & $1.2 \pm 0.4$ \\
PMMA 10\%CoA12 & $20 \pm 5.7$ & $2.0 \pm 0.2$ & $1.0 \pm 0.3$ \\
PMMA 5\% ZnA12 & $35 \pm 6.4$ & $2.9 \pm 0.5$ & $1.2 \pm 0.3$ \\
PMMA 10\% ZnA12 & $31 \pm 5.1$ & $3.0 \pm 0.6$ & $1.0 . \pm 0.3$ \\
PMMA 5\% ZnA13 & $32 \pm 9.1$ & $2.9 \pm 0.3$ & $1.1 \pm 0.2$ \\
PMMA 10\%ZnA13 & $25 \pm 4.4$ & $2.6 \pm 0.3$ & $1.0 \pm 0.2$ \\
\hline
\end{tabular}

Table 2: TGA summary results of PMMA-LDHs at $20^{\circ} \mathrm{C} \mathrm{min}^{-1}$ (N2)a

\begin{tabular}{|c|c|c|c|c|c|}
\hline Material & $T_{0}, T^{\circ} \mathrm{C}(\Delta T)$ & $T_{0} s^{\circ} \mathrm{C}(\Delta T)$ & Material & $T_{a_{2}} l \mathrm{C}(\Delta T)$ & $T_{0} y^{\prime} \mathrm{C}(\Delta T)$ \\
\hline PMMA & 285 & 365 & PMMA & 285 & 365 \\
\hline PMMA $5 \%$ NiA 12 & $317(32)$ & 150 (15) & PMAMA $10 \% / \mathrm{NiA} 12$ & $324(39)$ & $385(20)$ \\
\hline PMMA $5 \%$ CoA12 & $298(13)$ & 186 (21) & PMMA jof $C$ CON12 & 300 (15) & $388(23)$ \\
\hline PMMA $5 \% \mathrm{CuA12}$ & $237(-48)$ & $294(-21)$ & PMMA $105 \mathrm{CuA} 12$ & $236(-49)$ & $306(-59)$ \\
\hline PMMA $5 \%, 2 \mathrm{nA} 12$ & $299(14)$ & $3 \times 3(18)$ & PMMA $10 \% \mathrm{CuA} 12$ & $304(199)$ & $391(26)$ \\
\hline
\end{tabular}

Table 3: TGA summary results of PMMA-LDHs at $20^{\circ} \mathrm{C} \mathrm{min}^{-1}$ (air)

\begin{tabular}{lll}
\hline Material & $T_{0.1} /{ }^{\circ} \mathrm{C}(\Delta T)$ & $T_{0.5}{ }^{\circ} \mathrm{C}(\Delta T)$ \\
\hline PMMA & 268 & 345 \\
PMMA $5 \%$ NiA12 & $309(41)$ & $373(28)$ \\
PMMA 5\% CoA12 & $302(33)$ & $378(33)$ \\
PMMA 5\%ZnA12 & $302(33)$ & $381(36)$ \\
\hline
\end{tabular}

Journal of Materials Chemistry, Vol. 18, No. 26 (2008): pg. 3091-3102. DOI. This article is @ Royal Society of Chmistry and permission has been granted for this version to appear in e-Publications@Marquette. Royal Society of Chmistry does not grant permission for this article to be further copied/distributed or hosted elsewhere without the express permission from Royal Society of Chmistry. 
NOT THE PUBLISHED VERSION; this is the author's final, peer-reviewed manuscript. The published version may be accessed by following the link in the citation at the bottom of the page.

Table 4: Cone summary results of PMMA-LDHs (50 kW m-2)a

\begin{tabular}{|c|c|c|c|c|c|}
\hline Formulation & $\begin{array}{l}\text { PHRR/kW m } \\
\text { (\% reduction) }\end{array}$ & THR/MU m $=$ & ASEA $\mathrm{ma}^{2} \mathrm{~kg}$ ? & $A M L R / g>m=$ & 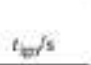 \\
\hline PMMA & $1057=25(\mathrm{NA})$ & $73 \pm 4$ & $102=71$ & $32.1 \pm 0.8$ & $22 \pm 3.5$ \\
\hline PMMA $1 \%$ NiA 12 & $1015=124(4)$ ? & $73 \pm 0$ & $194=47$ & $31.6 \pm 0.1$ & $21 \pm 1.6$ \\
\hline PMMA $5 \%$ NiA12 & $957 \pm 114(9)$ & $71 \pm 1$ & $348 \pm 18$ & $29.1 \pm 2.7$. & $20 \pm 1.7$ \\
\hline PMMA $10 \%$, NiA 12 & $886 \pm 27(16)$ & $71 \pm 2$ & $142 \pm 7$ & $27,3 \pm 0,4$ & $17 \pm 3.4$ \\
\hline PMMA $1 \% \mathrm{COA}_{12}$ & $1090=6\{0\}$ & $69 \pm 1$ & $132 \pm 7$ & $33.4 \pm 0.4$ & $22 \pm 13$ \\
\hline PMMA $5 \%$ CoA]2 & $787 \pm 54(26)$ & $73 \pm 1$ & $148 \pm 25$ & $25.5 \pm 1.3$ & $21 \pm 10$ \\
\hline PMMA $10 \% \mathrm{CoA} 12$ & $624 \pm 29(41)$ & $75 \pm 1$ & $191=6$ & $20.2 \pm 1.6$ & $19 \pm 0.7$ \\
\hline PMMA $1 \%, \mathrm{ZnA} 12$ & $1025+59(3)$ & $73 \pm 2$ & $105=?$ & $30.1 \pm 0.5$ & $18 \pm 14$ \\
\hline PMMA $5 \% \mathrm{ZnA} 12$ & $865 \pm 29(18)$ & $68 \pm 1$ & $110 \pm 3$ & $27.7 \pm 0.8$ & $16 \pm 3.9$ \\
\hline PMMA $10 \% \mathrm{ZnA} / 2$ & $785 \pm 22(26)$ & $66 \pm 1$ & $121 \pm 5$ & $25.9 \pm 0.8$ & $16 \pm 12$ \\
\hline
\end{tabular}

Table 5: Cone summary results of PMMA-ZnAl3 LDH (50 kW m-2)a

\begin{tabular}{|c|c|c|c|c|c|}
\hline Formulation & $\begin{array}{l}\text { PHRR/KW m } \\
\text { ( } \% \text { reduction) }\end{array}$ & THR/M m " & 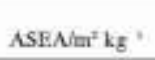 & $A M I R / g s m=$ & $t_{\varphi p} / s$ \\
\hline PMMA & $1057 \pm 25$ (NA) & $73 \pm 4$ & $102 \pm 71$ & $32.1 \pm 0.8$ & $22 \pm 3.5$ \\
\hline PMMA ZnA13 15, & $1049 \pm 36$ (1) & $73 \pm 1$ & $185 \pm 12$ & $3] .4 \pm 1.2$ & $21=12$ \\
\hline PMMA ZnA13 5\%, & $769 \pm 68(27)$ & $72 \pm 2$ & $253 \pm 19$ & $24.5 \pm 1.7$ & $18=26$ \\
\hline PMMA ZnA13 $10 \%$ & $61 \pm 51$ (35) & $71 \pm 1$ & $274 \pm 62$ & $201 \pm 1.8$ & $17 \pm 1.2$ \\
\hline
\end{tabular}

${ }^{a}$ PHRR, peak beat fetease rate; THR, total beat released; ASEA, average specifiectibction ares (a measurv of sinoke produced); A MLR, average mass loss nate; has, timetorignition.

Table 6: Fire performance index, FPI and fire growth rate, FIGRA for selected samples

\begin{tabular}{|c|c|c|c|c|c|}
\hline Formulation & $40 / s$ & PHRR/KW m $\mathrm{m}^{-1}$ & Time to PHRR/s & FPI $\times 1000 \mathrm{sm}^{2} \mathrm{~kW}$ & FIGRANW 5 ' m = \\
\hline PMMA & $22 \pm 3.5$ & $1057 \pm 25$ & $96 \pm 7.1$ & $21 \pm 32$ & $11=0.9$ \\
\hline PMMA $10 \%, \mathrm{Ni} A 12$ & $\overrightarrow{17}+34$ & $886=27$ & $101+2.0$ & $19 \pm 34$ & $9 \neq 0 ;$ \\
\hline PMMA $10 \% \mathrm{CaA12}$ & $19 \pm 0.7$ & $624 \pm 29$ & $105 \pm 4.2$ & $30 \pm 67$ & $6 \pm 0.4$ \\
\hline PMMA $10 \% \mathrm{ZnA12}$ & $16 \pm 12$ & $785 \pm 22$ & $98 \pm 2.1$ & $20 \pm 3.5$ & $8 \pm 1.2$ \\
\hline PMMA $10 \%, \mathrm{ZnA} 13$ & $17 \pm 1.8$ & $691=51$ & $84 \pm 20$ & $25 \pm 69$ & $8 \pm 0.6$ \\
\hline
\end{tabular}

Journal of Materials Chemistry, Vol. 18, No. 26 (2008): pg. 3091-3102. DOI. This article is @ Royal Society of Chmistry and permission has been granted for this version to appear in e-Publications@Marquette. Royal Society of Chmistry does not grant permission for this article to be further copied/distributed or hosted elsewhere without the express permission from Royal Society of Chmistry. 


\section{(Supporting information)}

\section{Aluminum-containing layered double hydroxides: the thermal, mechanical, and fire properties of (nano)composites of poly(methyl methacrylate)}

By Charles Manzi-Nshuti, Dongyan Wang, Jeanne M. Hossenlopp, and Charles A. Wilkie

Figure S1 illustrates the XRD patterns of the 5 LDHs used in this work. The strongest diffraction peaks are in the range of $2.86-3.23^{\circ}$ ( 2 $\theta$ ) and the basal spacings of these materials are in the range 3.10$2.70 \mathrm{~nm}$. The spacing was found $2.76 \mathrm{~nm}$ for CuAl2, $2.73 \mathrm{~nm}$ for CoAl2, $2.70 \mathrm{~nm}$ for NiAl2 and $2.74 \mathrm{~nm}$ for $\mathrm{ZnAl2}$, but $3.10 \mathrm{~nm}$ for ZnAl3. The basal spacings thus were found not to depend on the type of divalent metal, but do depend on divalent/trivalent ratio for the zinc aluminum systems.

Since the thickness of the M(II)Al hydroxide sheet is around $4.77 \AA,{ }^{1}$ one can subtract this from the basal spacing to get the interlayer spacings, which are $2.25 \mathrm{~nm}$ (CoAl2), $2.28 \mathrm{~nm}$ (CuAl2), 2.22 $\mathrm{nm}(\mathrm{NiAl} 2), 2.26 \mathrm{~nm}(\mathrm{ZnAl} 2)$ and $2.62 \mathrm{~nm}(\mathrm{ZnAl} 3)$. The length of $10-$ undecenoate anion (farthest distance between one carboxylate oxygen and one hydrogen from the terminal $\mathrm{CH} 2$ group) was calculated to be $1.44 \mathrm{~nm}$ (RHF/6-311G*); it is likely that the tails of the undecenoate anions are partially interdigitated in the interlamellar space of the ZnAl2, CuAl2, CoAl2 and NiAl2. A similar model of the interdigitated anions in the gallery space of an LDH has been reported. ${ }^{2}$ However, one cannot rule out the possibility of a bilayer arrangement with high angle of tilt.

The size of the gallery space is not controlled by the nature of the cations in the brucite-like layers, but it is mainly controlled by the size of the anion. In this case, however, the relative stoichiometry matters. Ulibarri et co-workers ${ }^{3}$ who synthesized a CoAl-CO3 LDH and noted that the unit layer thickness of their LDH was of the same order relative to other hydrotalcite materials with carbonate anions and water molecules in the interlayer space. ${ }^{4} \mathrm{ZnAl} 3$ had the largest basal spacing relative to the other LDHs. In this case, a partially interdigitated or a tilted bilayer anionic arrangement in the gallery of this LDH can be suggested. Close analysis of the XRD patterns of CoAl2 and NiAl2 (figure S1) shows for both materials broad diffraction

Journal of Materials Chemistry, Vol. 18, No. 26 (2008): pg. 3091-3102. DOI. This article is @ Royal Society of Chmistry and permission has been granted for this version to appear in e-Publications@Marquette. Royal Society of Chmistry does not grant permission for this article to be further copied/distributed or hosted elsewhere without the express permission from Royal Society of Chmistry. 
peaks; the breath of the diffraction peaks may indicate some degree of disorder in the packing of the layers of these materials and a smaller degree of stacking as shown later in this text. The other LDHs, CuAl2, ZnAl2 and ZnAl3 (figure S1) have sharp XRD peaks. The presence of higher order diffraction peaks (006) and (009) for the latter indicates that the layers of these materials are pronounced. From the XRD traces of these LDHs, the coherence length in the stacking direction was estimated using the Debye-Scherrer equation, $T=k \lambda /\left(\beta_{\mathrm{T}} \cos \theta\right)$ where $\theta$ is the diffraction angle, $k$ is a constant ( 0.9 for powders) ${ }^{5}$, $\beta 1 / 2$ is the full width at half maximum height of a diffraction peak of the layered material after correction for $\mathrm{CuKa}_{2}$ and the instrumental broadening and $\lambda$ is the $X$-ray wavelength, 1.54078 for CuKa ${ }_{1}$. The instrument response was obtained using the National Institute of Standards and Technology (NIST) standard reference material Si powder (SRM 640C). The smallest domain sizes were found for CoAl2 (approximately $7 \mathrm{~nm}$ corresponding to about two to three stacked layers and NiAl2 ( found to be approximately $11 \mathrm{~nm}$ corresponding to about 4 stacked layers), while CuAl2, ZnAl2 and ZnAl3 had about 25 $\mathrm{nm}, 28 \mathrm{~nm}$ and $31 \mathrm{~nm}$ respectively, corresponding to about 9-10 stacked layers.

The FT-IR spectra of the 5 layered materials synthesized in this study are shown in Figure S2. These spectra are very similar and support the fact that the undecenoate anion has been intercalated in the galleries of all 5 LDHs. Assignments of the different bands correlate with the MgAl-undecenoate LDH reported by Wang and coworkers. ${ }^{6}$ The two bands in the range of $910-1000 \mathrm{~cm}^{-1}$ correspond to the out-of-plane $\mathrm{C}-\mathrm{H}$ bending vibrations. The strong absorption peaks in the range of $1600-1430 \mathrm{~cm}^{-1}$ are assigned to the asymmetric and symmetric stretching vibrations, respectively of $\mathrm{RCOO}^{-6}$. The $\mathrm{C}=\mathrm{C}$ stretching vibration is around $1640 \mathrm{~cm}^{-1}$ and a very small shoulder corresponding to the $\mathrm{C}-\mathrm{H}$ stretching vibration for the $\mathrm{sp}^{2}$ carbon of the 10-undecenoate anion is located around $3080 \mathrm{~cm}^{-1}$. The strong and broad absorption peak near $3400 \mathrm{~cm}^{-1}$ is attributed to the $-\mathrm{OH}$ group in both the LDH sheets and the interlayer water molecules. ${ }^{8}$ It is possible that a small amount of carbonate anions, below the detection limit of the FT-IR instrument, is also present. The synthesis was carried out under nitrogen, but the very strong affinity of the LDH for permission has been granted for this version to appear in e-Publications@Marquette. Royal Society of Chmistry does not grant permission for this article to be further copied/distributed or hosted elsewhere without the express permission from Royal Society of Chmistry. 
carbonate make, the synthesis of these materials very difficult if one wants to make carbonate-free materials, because the binding of monovalent anions is less than that of higher charged species in aqueous solution. ${ }^{9}$ Iyi et al. ${ }^{10}$ reported the trend in the affinity of the $\mathrm{LDH}$ toward various anions to be in the following order: ${ }^{11}$

$$
\mathrm{CO}_{3}{ }^{2-}>\mathrm{SO}_{4}{ }^{2-}>\mathrm{OH}^{-}>\mathrm{F}^{-}>\mathrm{Cl}^{-}>\mathrm{Br}^{-}>\mathrm{NO}_{3}^{-}>\mathrm{I}^{-}
$$

At any stage in the synthesis of the LDH (from boiling and degassing the water used in the synthesis to drying the final solid LDH in the vacuum oven), contamination is difficult to avoid. ${ }^{12}$ The absence of a nitrate band ( $a$ strong band $\sim 1380 \mathrm{~cm}^{-1}$ ) or the carbonate band ( $\mathrm{a}$ strong band $\sim 1365 \mathrm{~cm}^{-1}$ ) and the presence of the bands characteristics of the undecenoate anion as described above may suggest that the latter anion is largely incorporated between the layers of the LDH.

The melt blending of the polymer in Brabender mixer could cause some degradation. In order to confirm that this has not occurred, the TGA curves for virgin PMMA and a sample that have been mixed in the Brabender are compared below and one can see that degradation does not occur upon mixing; the curves roughly overlay and are shown in Figure S3.

\section{Notes}

1. V.R.L. Constantino T.J. Pinnavaia, Inorg. Chem. 1995, 34, 883.

2. W. Chen B. Qu, B. Chem. Mater. 2003, 15, 3208.

3. M. A. Ulibarri, J. M. Fernández, F. M. Labajos, V. Rives, V. Chem. Mater. $1991,3,626$.

4. C. J. Serna, J. L. Rendón, J. E. Iglesias, Clays Clay Miner. 1982, 30, 180.

5. R. Jenkins, R. L. Synder, Introduction to X-ray Powder Diffractometry; Wiley: New York, 1996.

6. G.-A. Wang, C.C. Wang, C. Y.Chen, Polymer 2005, 46, 5065.

7. K. M. McGrath, Colloid. Polym. Sci. 1996, 274, 499.

8. M. Taibi, S. Ammar, N. Jouini, F. Fiëvet, P. Molinié, M. Drillon, J. Mater. Chem. 2002, 12,3238.

9. K. Chibwe, W. J. Jones, J. Chem. Soc.,Chem.Commun.1989, 14, ,926.

10. N. Iyi, T. Matsumoto, Y. Kaneko, K. Kitamura, K. Chem. Mater. 2004, 16, 2926.

11. S. Miyata. Clays Clay Miner. 1983, 31, 305.

12. F. Leroux, J. Besse,. Chem. Mater. 2001, 13, 3507.

Journal of Materials Chemistry, Vol. 18, No. 26 (2008): pg. 3091-3102. DOI. This article is @ Royal Society of Chmistry and permission has been granted for this version to appear in e-Publications@Marquette. Royal Society of Chmistry does not grant permission for this article to be further copied/distributed or hosted elsewhere without the express permission from Royal Society of Chmistry. 
NOT THE PUBLISHED VERSION; this is the author's final, peer-reviewed manuscript. The published version may be accessed by following the link in the citation at the bottom of the page.

\section{Appendix}

Figure S1. XRD traces of undecenoate containing LDHs of CoAl2, NiAl2, CuAl2, ZnAl2 and ZnAl3.

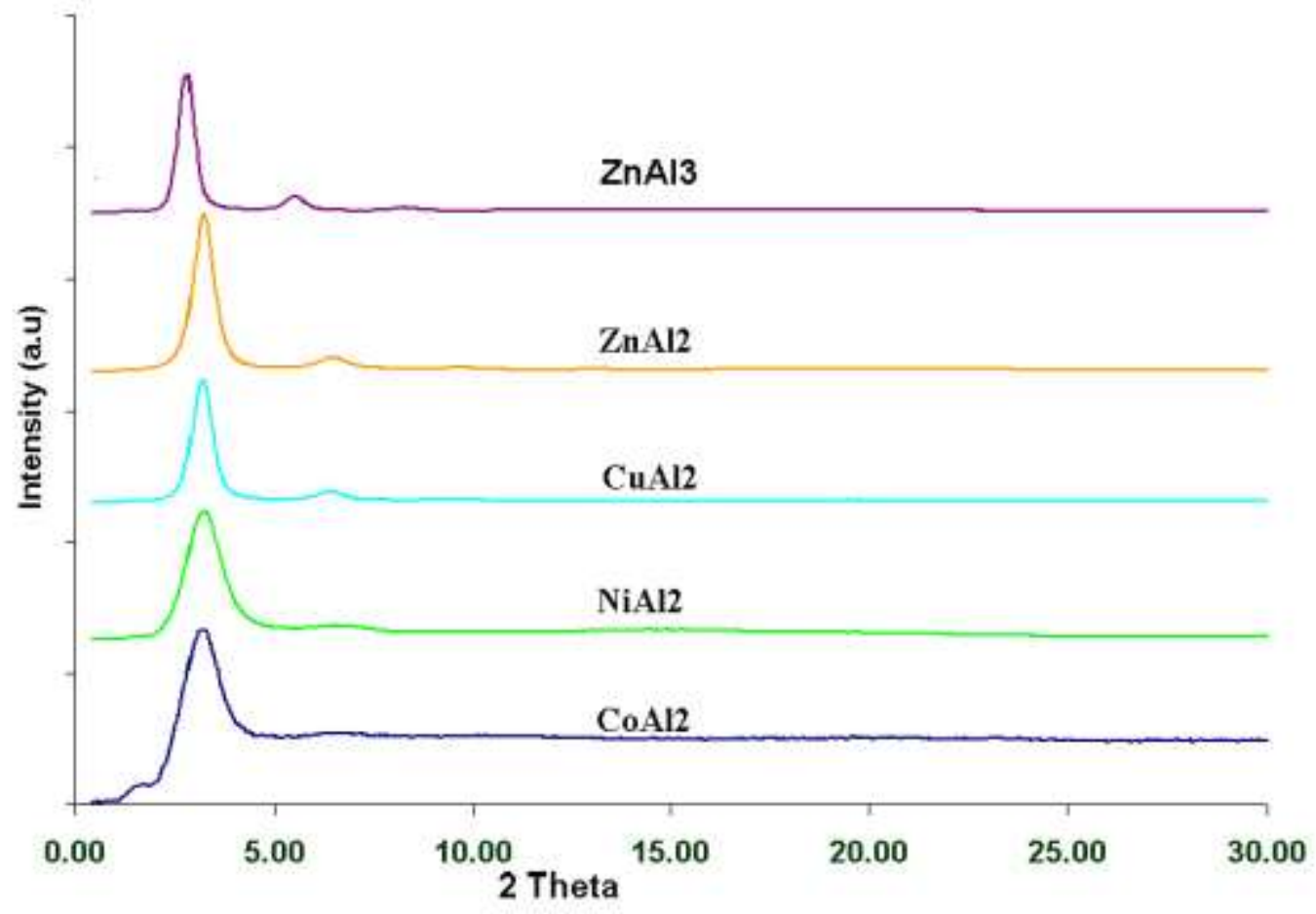

Journal of Materials Chemistry, Vol. 18, No. 26 (2008): pg. 3091-3102. DOI. This article is (c) Royal Society of Chmistry and permission has been granted for this version to appear in e-Publications@Marquette. Royal Society of Chmistry does not grant permission for this article to be further copied/distributed or hosted elsewhere without the express permission from Royal Society of Chmistry. 
NOT THE PUBLISHED VERSION; this is the author's final, peer-reviewed manuscript. The published version may be accessed by following the link in the citation at the bottom of the page.

Figure S2: FT-IR of different undecenoate LDHs : (A) CoAl2; (B) CuAl2; (C) NiAl2; (D) ZnAl2 and (E) ZnAl3.

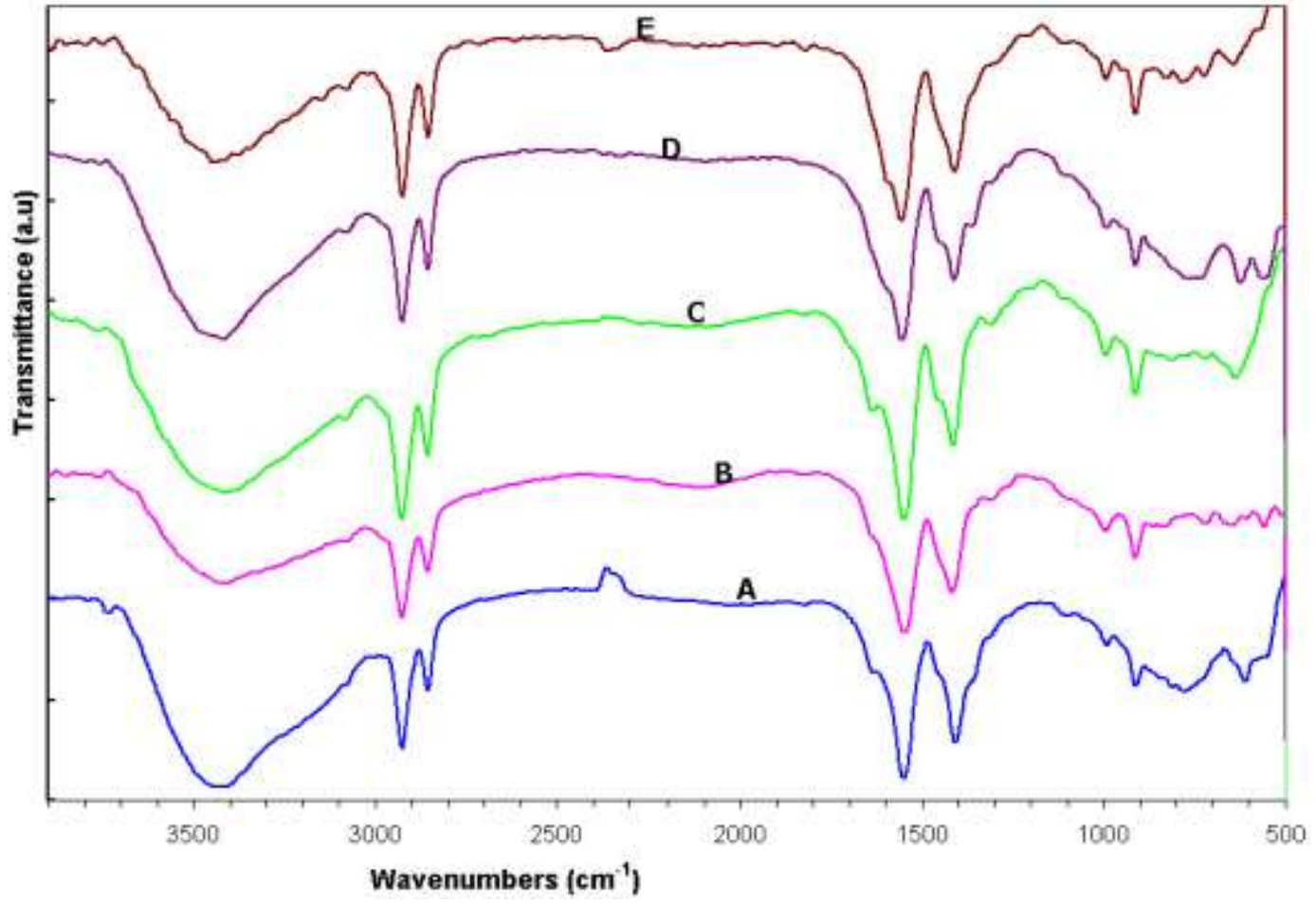

Journal of Materials Chemistry, Vol. 18, No. 26 (2008): pg. 3091-3102. DOI. This article is (c) Royal Society of Chmistry and permission has been granted for this version to appear in e-Publications@Marquette. Royal Society of Chmistry does not grant permission for this article to be further copied/distributed or hosted elsewhere without the express permission from Royal Society of Chmistry. 
NOT THE PUBLISHED VERSION; this is the author's final, peer-reviewed manuscript. The published version may be accessed by following the link in the citation at the bottom of the page.

Figure 53: TGA curves of commercial PMMA (A) and the same polymer melt blended for $7 \mathrm{~min}$ in a Brabender mixer at $185^{\circ} \mathrm{C}(\mathrm{B})$. (TGA, N2, $20^{\circ} \mathrm{C} / \mathrm{min}$ ).

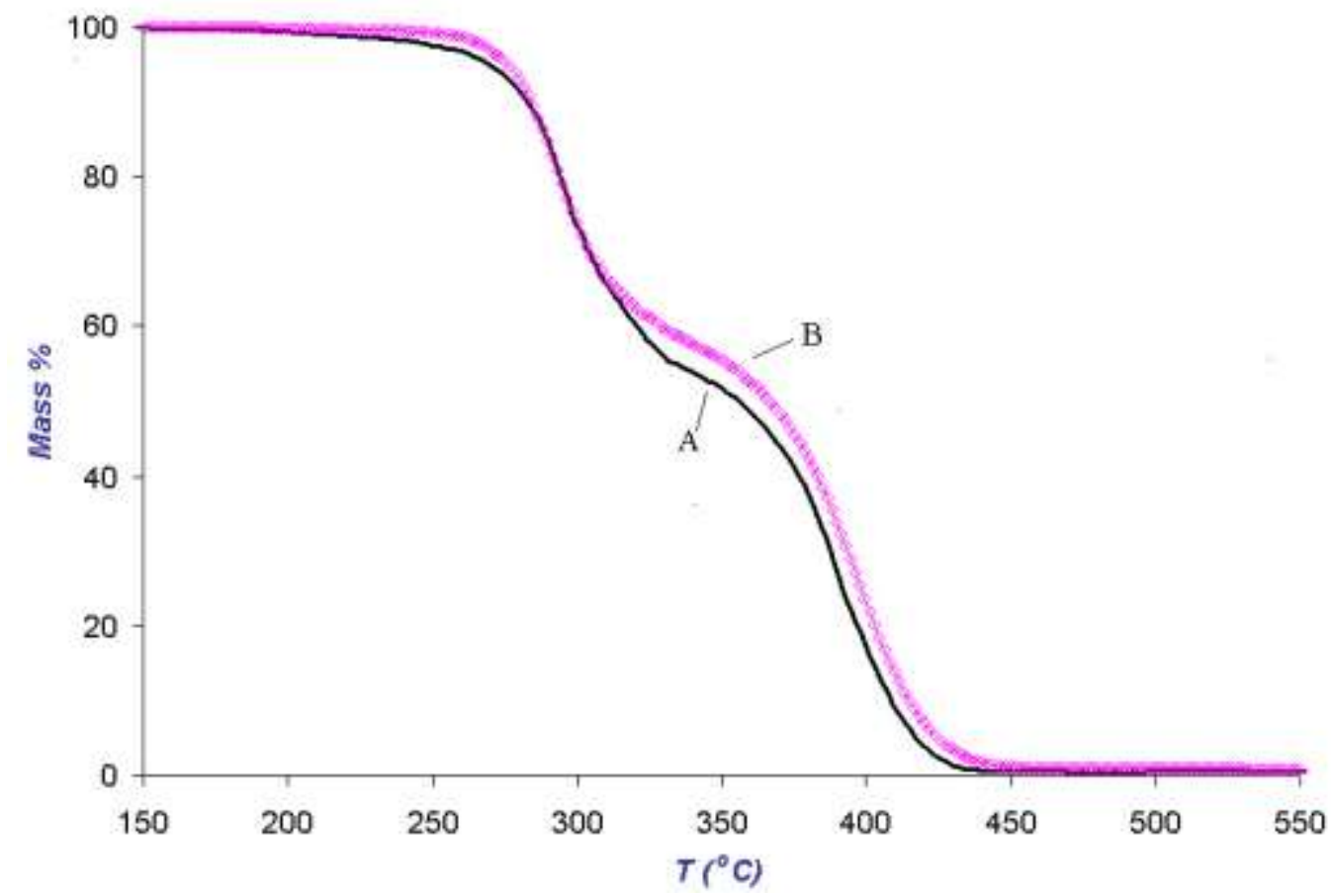

Journal of Materials Chemistry, Vol. 18, No. 26 (2008): pg. 3091-3102. DOI. This article is @ Royal Society of Chmistry and permission has been granted for this version to appear in e-Publications@Marquette. Royal Society of Chmistry does not grant permission for this article to be further copied/distributed or hosted elsewhere without the express permission from Royal Society of Chmistry. 